\title{
Comparative transcriptional profiling of the limbal epithelial crypt demonstrates its putative stem cell niche characteristics
}

\author{
Bina B Kulkarni', Patrick J Tighe², Imran Mohammed', Aaron M Yeung ${ }^{1}$, Desmond G Powe ${ }^{2}$, Andrew Hopkinson',
} Vijay A Shanmuganathan ${ }^{1}$, Harminder S Dua ${ }^{1 *}$

\begin{abstract}
Background: The Limbal epithelial crypt (LEC) is a solid cord of cells, approximately 120 microns long. It arises from the undersurface of interpalisade rete ridges of the limbal palisades of Vogt and extends deeper into the limbal stroma parallel or perpendicular to the palisade. There are up to 6 or 7 such LEC, variably distributed along the limbus in each human eye.

Morphological and immunohistochemical studies on the limbal epithelial crypt (LEC) have demonstrated the presence of limbal stem cells in this region. The purpose of this microarray study was to characterise the transcriptional profile of the LEC and compare with other ocular surface epithelial regions to support our hypothesis that LEC preferentially harbours stem cells (SC).

Results: LEC was found to be enriched for SC related Gene Ontology (GO) terms including those identified in quiescent adult SC, however similar to cornea, limbus had significant GO terms related to proliferating SC, transient amplifying cells (TAC) and differentiated cells (DC). LEC and limbus were metabolically dormant with low protein synthesis and downregulated cell cycling. Cornea had upregulated genes for cell cycling and self renewal such as FZD7, BTG1, CCNG, and STAT3 which were identified from other SC populations. Upregulated gene expression for growth factors, cytokines, WNT, Notch, TGF-Beta pathways involved in cell proliferation and differentiation were noted in cornea. LEC had highest number of expressed sequence tags (ESTs), downregulated and unknown genes, compared to other regions. Genes expressed in LEC such as CDH1, SERPINF1, LEF1, FRZB1, KRT19, SOD2, EGR1 are known to be involved in SC maintenance. Genes of interest, in LEC belonging to the category of cell adhesion molecules, WNT and Notch signalling pathway were validated with real-time PCR and immunofluorescence.

Conclusions: Our transcriptional profiling study identifies the LEC as a preferential site for limbal SC with some characteristics suggesting that it could function as a 'SC niche' supporting quiescent SC. It also strengthens the evidence for the presence of "transient cells" in the corneal epithelium. These cells are immediate progeny of SC with self-renewal capacity and could be responsible for maintaining epithelial turn over in normal healthy conditions of the ocular surface (OS). The limbus has mixed population of differentiated and undifferentiated cells.
\end{abstract}

\section{Background}

Corneal transparency is crucial for sight. The corneal epithelium and tear film provide the polished outer surface to the cornea enabling it to function as a refractive surface. It is postulated that the continued supply of the epithelial cells is maintained by the SC at the limbus.

\footnotetext{
* Correspondence: Harminder.Dua@nottingham.ac.uk

'Division of Ophthalmology and Visual Sciences, B-Floor, Eye \& ENT Building

Queen's Medical Centre, Derby Road, Nottingham, UK

Full list of author information is available at the end of the article
}

Numbers of studies have provided direct and indirect evidence to support this notion. In 1986 Schermer et al proposed the limbal location of corneal stem cells based on keratin expression of corneal epithelial cells [1]. Other studies providing evidence of presence of corneal stem cells at limbus include immunohistochemistry studies with known SC markers [2-4], cell cycling studies characterising the limbal-basal epithelium $[5,6]$ and electron microscopic features of the basal epithelial cells [7]. We have identified a unique structure at the limbus,

\section{() Biomed Central}



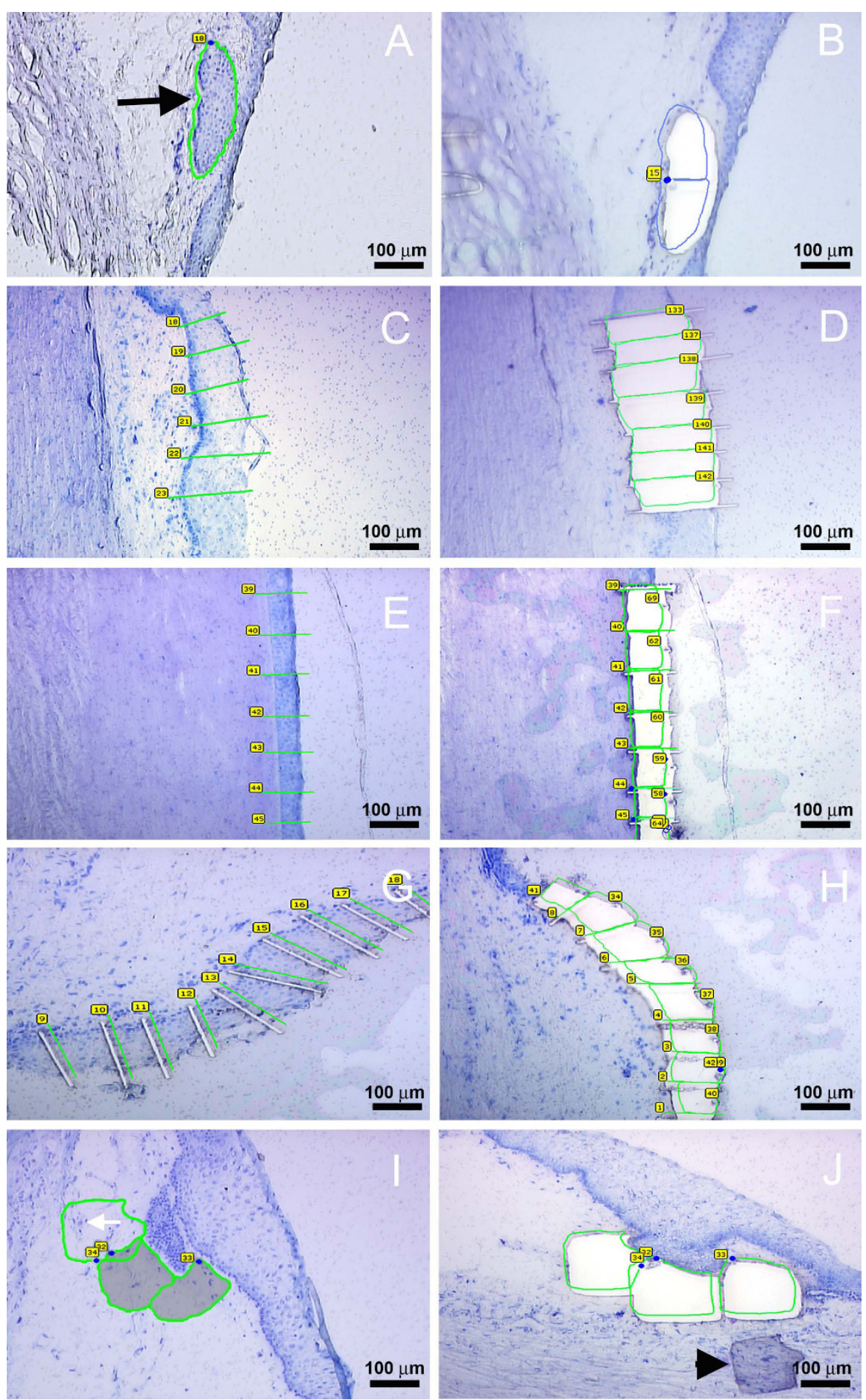

Figure 1 Laser Microdissection (LMD) of the ocular surface epithelial regions. The composite shows steps of LMD performed on radial cut section of LEC ( $A, B$,), limbus $(C, D)$, cornea $(E, F)$, conjunctiva $(G, H)$ and LEC stroma $(I, J)$ at 20x magnification (scale bars shown). Figure $1 A$ is of pre LMD LEC, shown with black arrow. Figure 1 I is of LEC stroma with cells shown with white arrow. Prior to LMD, the sections were stained with RNase free Toluidine Blue. Images (A, $C, E, I$, ) are examples of pre LMD OS epithelial region sections with outlines for laser cuts drawn around the tissue. The junctions between the OS epithelial regions were avoided as it has overlapping features of the two adjacent regions. Image $(G)$ shows cut sections of the epithelial regions. Dividing the epithelium into multiple small pieces facilitated effective catapulting of the tissue into the collection cap. Images ( $B, D, F, H, J)$ represent examples of post LMD sections of OS epithelium following pressure catapulting of the epithelial pieces. Image J shows a misdirected piece of LEC Stroma which was not captured in the cap but settled down over the adjacent LEC Stroma (black arrow head); such tissue pieces could be recatapulted into the cap with dot LPC laser function. 
termed as the limbal epithelial crypt (LEC) [8]. It is a solid cord of cells which extends from the peripheral aspect of the undersurface of interpalisade rete ridges of limbal palisades of Vogt into the limbal stroma (Figure 1A). There are up to 6 or 7 such LEC, variably distributed along the limbus in each human eye. The LEC is analogous to the deep ridges reported in the monkey palm epithelium, where the basal cells of the deep ridges are shown to be the slow cycling stem cells. Similar to the deep location of the ridges in the monkey palm, the deep location of the LEC would offer physical protection to the SC population $[9,10]$. Our anatomical and immunohistological studies on the LEC have emphasised its potential as a repository of SC and as a putative SC niche (SCN) [11,12], a concept first proposed by Schofield in 1978 [13]. Constituents of the niche include tissue cells, and extra-cellular substrates that sustain the $\mathrm{SC}$ and control their self renewal and progenitor potential in vivo [14]. The niche provides a specialised microenvironment whereby SC are maintained in a state of quiescence. Cellular quiescence indicates slow cell cycling or growth arrested phase of the cells. In adult $\mathrm{SC}$ it protects against environmental stresses and aids in their maintenance. This property was identified in various cell populations such as in the bulge region of hair follicles [15], intestinal [16], haematopoietic [17], muscle satellite SC [18] and also in the limbus [19]. In the hair follicle bulge region two SC compartments have been identified [15]; the quiescent and the activated progenitor cells. The latter regenerates the tissue in homeostatic conditions whereas; quiescent cells act as a reservoir and undergo cell cycling following tissue injury. Several studies have identified possible SC markers in the limbal epithelium, using a mechanical dissection technique [20-22]. This method potentially involves the risk of contamination from surrounding tissue. However, laser microdissection (LMD) has allowed the isolation of a pure population of both limbal and corneal epithelium in situ [23]. Studies have also been performed on limbal sub-populations using different techniques including cell cultures [24], collagen adhesiveness [25] and flow cytometry [26]. However such methods involving cellular manipulation can influence gene expression. This transcriptional profiling study of laser microdissected OS epithelial regions (LEC, limbus, cornea, conjunctiva and LEC stroma) demonstrates the average characteristic features of each region rather than of the individual cell populations. Broadly, this study highlights the presence of undifferentiated and quiescent SC in the LEC and "transient cells" or activated progenitor cells and differentiated cells in the cornea [27]. The gene expression of limbus is suggestive of presence of quiescent cell population with differentiated suprabasal epithelial cells. Our study provides evidence to support the hypothesis that the LEC is the reservoir of the SC and could serve as a $\mathrm{SC}$ niche at the human OS.

\section{Results and Discussion}

Transcriptome analysis of OS regions; 1) LEC, 2) limbus, 3) cornea, 4) conjunctiva and 5) LEC stroma was performed on four biological replicates for each region, processed from four pairs of cadaver human eyes. Poor quality raw data from a corneal and a conjunctival replicate were excluded from the analysis. Following normalisation and filtration, a data set of 4574 genes for 18 samples was created.

\section{Differentially Expressed Gene Lists}

Principal Component Analysis (PCA) grouped the biological replicates for each OS region. Figure 2 (left) shows LEC replicates segregated from other OS regions. This demonstrated similarity and reproducibility amongst the LEC biological replicates. Notably, PCA of differentially expressed genes between LEC and cornea generated distinct gene clusters (figure 2, right) as these two regions are at the opposite ends of the epithelial differentiation spectrum. The differentially expressed gene list for each OS region demonstrated highest upregulated gene expression in the cornea and most downregulated genes in LEC. Our findings showed that cornea was the most biologically active zone, whereas the LEC was a metabolically dormant zone (table 1).

\section{Gene Ontology (GO)}

Considering the model of corneal epithelial regeneration [12,28-30], comparative GO profiling of LEC, limbus and cornea, was performed with the GO terms categorised according to specific functions [31] related to stem, transient amplifying (TAC) and differentiated cells (DC) $[32,33]$. SC related GO terms enriched in LEC and limbus were Transcription from RNA polymerase II promoter, regulation of transcription from RNA polymerase II promoter and RNA binding. Compare analysis performed on Ingenuity pathway analysis (IPA), characterised the 'tissue specific' nature of each region. LEC was found to be enriched for undifferentiation processes such as System development (4.2E-04), including spermatogenesis (SLC12A2), development of haematopoietic progenitor cells (EGR1) and nervous system development (LEF1, EGR1, PARK2, SLC12A2). This suggests that the LEC is a more undifferentiated and stem-like region than the adjoining limbus. Also down regulation of genes related to TAC terms, such as cell proliferation and apoptosis in LEC demonstrates its primitive features, unlike limbus. Meta-analysis performed by Edwards et al on SC microarray data sets have identified GO terms related to quiescent and proliferating SC [33]. Based on this study we have found that LEC was 


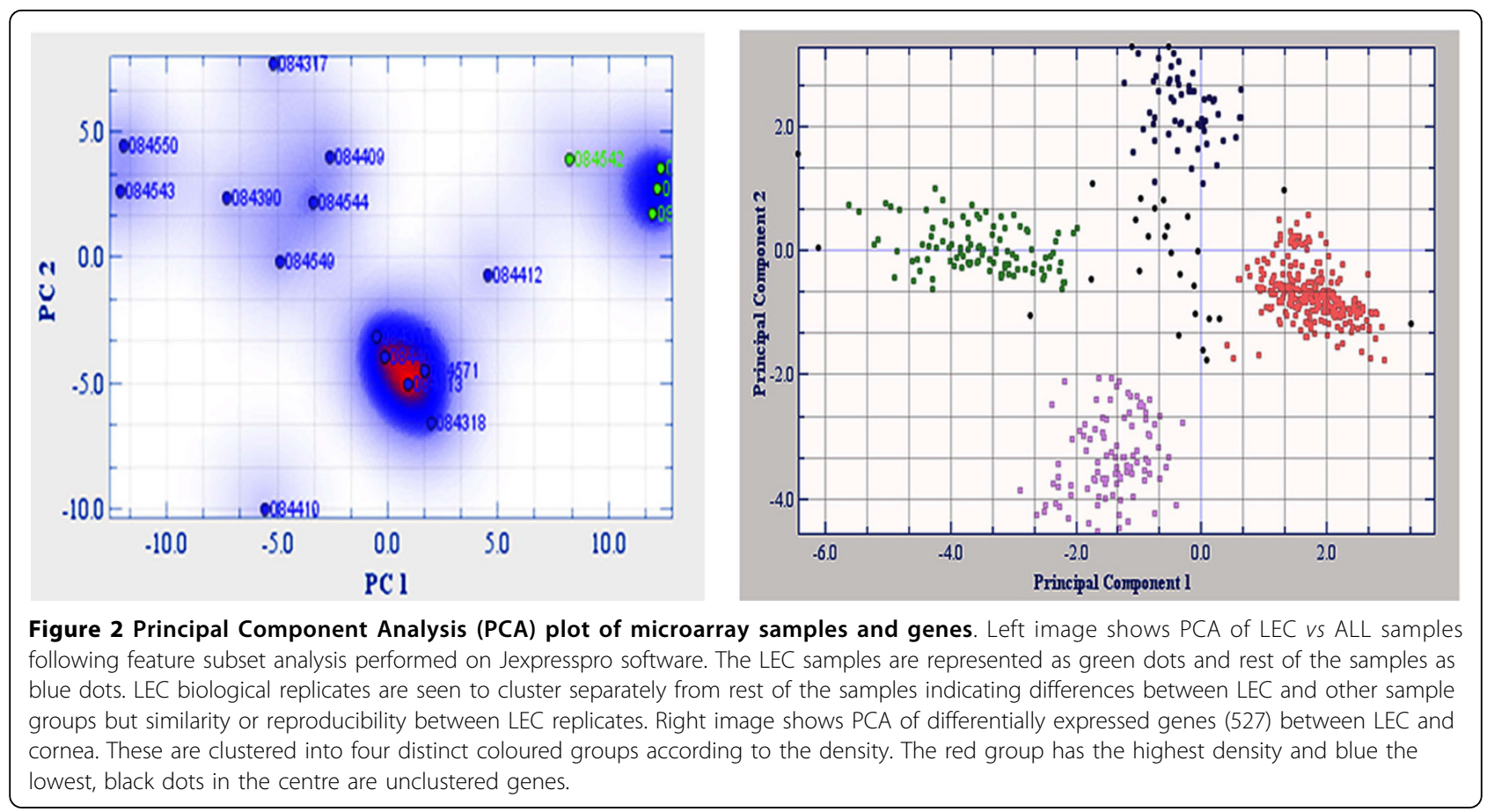

specifically enriched for quiescent SC (QSC) related terms such as Biological Regulation, (p value: 4.0E-2), and Regulation of cellular processes ( $\mathrm{p}$ value: $5.0 \mathrm{E}-2$ ) (figure 3A). However limbus [Protein folding (p value: $2.6 \mathrm{E}-2)]$ and cornea [Primary metabolic process ( $\mathrm{p}$ value: 7.1E-5), Translation (5.5E-11)] were enriched for PSC related GO terms. Additionally cornea and limbus were enriched for TAC and DC related GO terms (figure 3B).

\section{Molecular Features of stem/transient cells in OS regions}

Adult SC are quiescent or slow cycling, whilst their immediate progeny the "transient cells" (early TAC) and subsequent TAC undergo active cell cycling, proliferation and differentiation [34]. SC related GO terms further studied on DAVID 2008 using functional annotation clustering were: i) transcription factors; ii) self renewal, iii) cell proliferation; iv) cell differentiation; v) negative regulation of cell proliferation; and vi) cell cycling.

i) Transcription factors are involved in development and SC functions such as regulating cell fate determination, cell cycling, cell differentiation and response to environment. This GO term was significant only to LEC ( $p$ value: $3.50-05$ ) and limbus (p value: $5.70 \mathrm{E}-04$ ), (figure $3 \mathrm{~A}$, table 2). LEF1 has been shown to be crucial in hair follicle patterning [35] epithelial invagination into mesenchyme [36], and in maintenance of SC quiescence $[37,38]$, it was found to be upregulated in LEC. In contrast, the upregulated transcription factors in limbus were involved in cell proliferation and differentiation (table 2). A study on embryonic limbus has demonstrated expression of SOD2 (transcription factor and antioxidant) exclusively in limbus from 14 weeks of development [39]. However our microarray study had

Table 1 Differentially expressed gene lists of OS epithelial regions

\begin{tabular}{llllllll}
\hline Ocular Regions & Total genes & Up-reg genes & $\begin{array}{l}\text { Down-reg } \\
\text { genes }\end{array}$ & DAVID IDs & & IPA IDs \\
\hline LEC & & & & mapped & unmapped & mapped & unmapped \\
\hline Limbus & 704 & 95 & 609 & 483 & 115 & 548 & 156 \\
\hline Cornea & 463 & 169 & 294 & 294 & 79 & 355 & 106 \\
\hline LEC Stroma & 1649 & 1237 & 412 & 939 & 192 & 1273 & 370 \\
\hline Conj & 329 & 113 & 216 & 234 & 52 & 266 & 70 \\
\hline
\end{tabular}

In DAVID 2008 and Ingenuity Pathway Analysis the mapped gene IDs were analysed and the unmapped gene IDs were excluded as these were either unknown genes, ESTs, sequences or duplicated genes. 

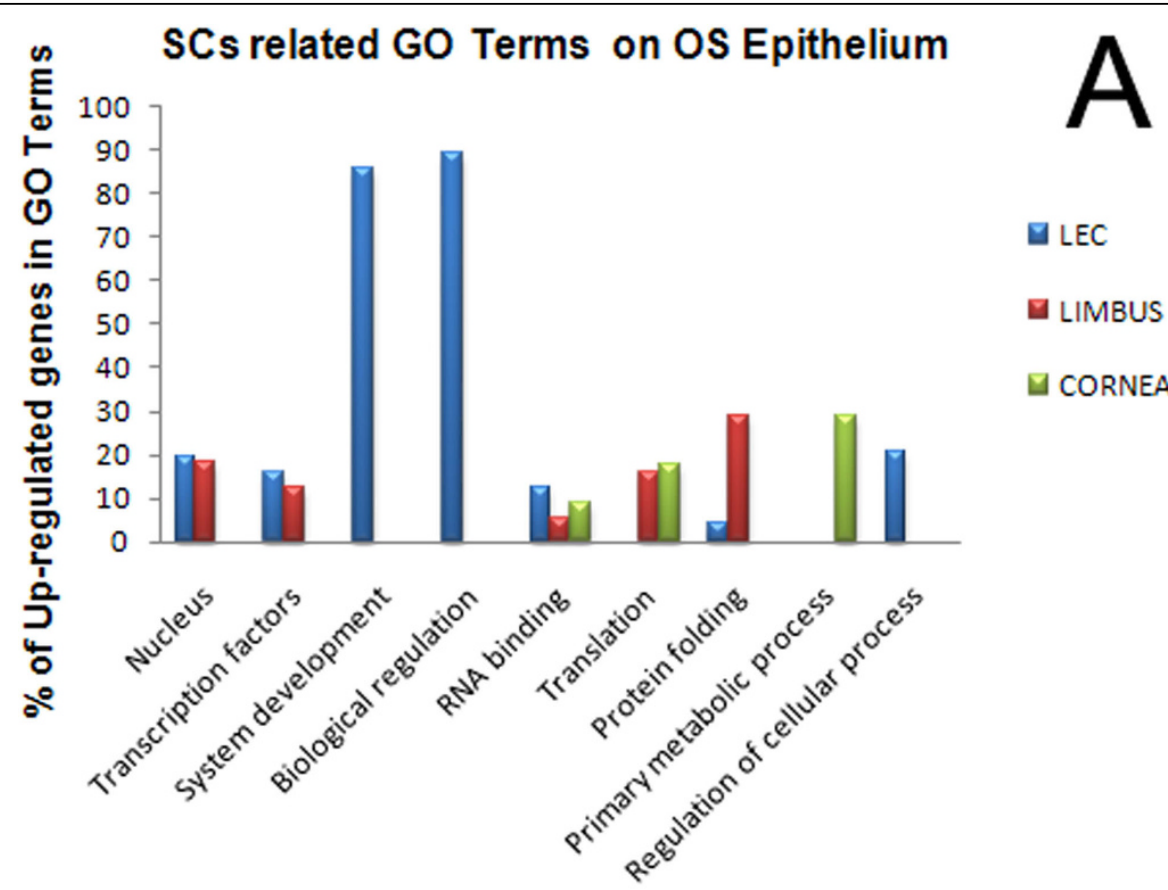

D LEC

回 LIMBUS

$\square$ CORNEA
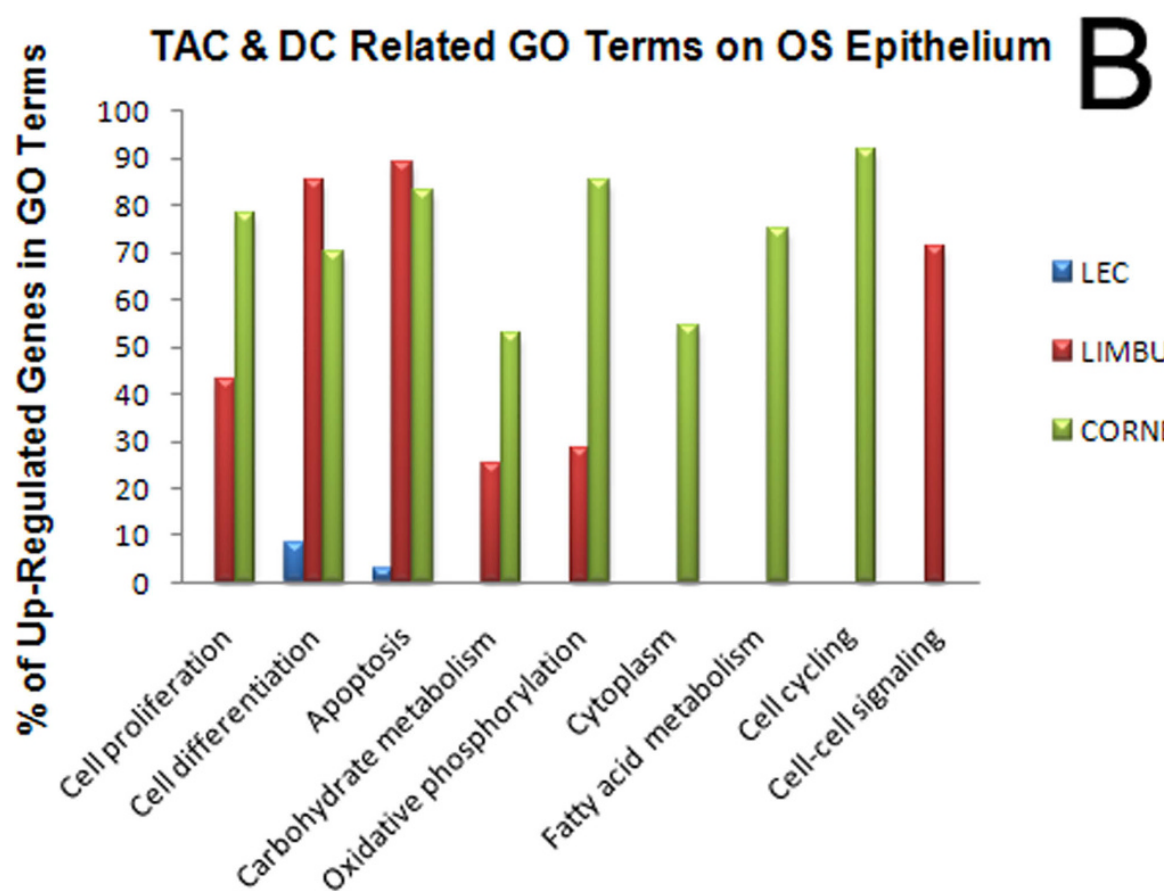

ㄴ.EC

GLIMBUS

$\square$ CORNEA

Figure 3 Composite image of Gene Ontology graphs. Bar graph (A) shows statistically significant ( $p$ value $\leq 0.05$ ) SC related GO terms in LEC, Limbus and cornea. Bar graph (B) represents statistically significant ( $p$ value $\leq 0.05$ ) TAC and DC related GO terms in LEC, limbus and cornea. In both graphs $A$ and $B$ the $x$ and $y$ axes indicate the $G O$ terms related to gene functions and percentages of differentially expressed upregulated genes in each category respectively. Absent bar chart for particular GO term in a region was either because of downregulated or absent gene expression.

noted upregulated expression of SOD2 in LEC, limbus and cornea (table 3)

ii) Self renewal is an important feature of SC maintenance, which isabsent in differentiated cells, weakly expressed in quiescent SC but significantly expressed in proliferating progenitor cells such as mesenchymal stem cells (MSC), [40], intestinal crypts and neural crest cells $[41,42]$. Based on other SC studies such as adult SC 
Table 2 Candidate genes expressed in SC related GO terms

\begin{tabular}{|c|c|c|c|c|c|}
\hline \multicolumn{2}{|c|}{ LEC } & \multicolumn{2}{|c|}{ Limbus } & \multicolumn{2}{|c|}{ Cornea } \\
\hline Accession No. & $\begin{array}{l}\text { Gene Symbol } \\
\text { (Foldchange) }\end{array}$ & Accession No. & $\begin{array}{l}\text { Gene Symbol } \\
\text { (Foldchange) }\end{array}$ & Accession No. & $\begin{array}{l}\text { Gene Symbol } \\
\text { (Fold change) }\end{array}$ \\
\hline \multicolumn{6}{|c|}{ Transcription factors (GO ID 0006366) } \\
\hline NM_001964 & EGR1 (1.8) & NM_000024 & ADRB2 (2.7) & - & - \\
\hline NM_016269 & LEF1 (1.3) & NM_006885 & ZFHX3 (1.5) & - & - \\
\hline NM_004492 & GTF2A2 (4.2) & NM_001537 & HSBP1 (1.7) & - & - \\
\hline NM_004290 & RNF14 (5.1) & NM_006237 & POU4F1 (1.9) & - & - \\
\hline NM_000636 & SOD2 (3.5) & NM_002165 & ID1 (1.5) & - & - \\
\hline NM_005997 & VPS72 (5.5) & NM_000636 & SOD2 (1.6) & - & - \\
\hline \multicolumn{6}{|c|}{ Self Renewal } \\
\hline NM_004360 & $\mathrm{CDH} 1$ (3.1) & NM_001537 & HSBP1 (1.7) & NM_001731 & BTG1 (3.0) \\
\hline NM_016269 & LEF1 (1.3) & - & - & NM_004060 & CCNG1 (1.7) \\
\hline- & - & - & - & NM_002592 & PCNA (8.8) \\
\hline- & - & - & - & NM_033632 & FBW7 (6.1) \\
\hline- & - & - & - & NM_003908 & EIF2S2 (4.9) \\
\hline- & - & - & - & NM_003507 & FZD7 (2.0) \\
\hline- & - & - & - & NM_001553 & IGFBP7 (9.7) \\
\hline- & - & - & - & BC004241 & LAMA4 (2.8) \\
\hline- & - & - & - & NM_000269 & NME1 (4.5) \\
\hline- & - & - & - & NM_003150 & STAT3 (1.7) \\
\hline- & - & - & - & NM_005524 & HES1 (2.1) \\
\hline \multicolumn{6}{|c|}{ Cell Proliferation (GO ID: 0008283) } \\
\hline- & - & NM_002350 & LYN (1.2) & NM_001421 & ELF4 (1.9) \\
\hline- & - & NM_004160 & PYY (2.4) & NM_002520 & NPM1 (8.5) \\
\hline- & - & NM_000024 & ADRB2 (2.7) & NM_153815 & RASGRF1 (6.2) \\
\hline- & - & & & NM_002272 & KRT5 (2.5) \\
\hline- & - & & & NM_005154 & USP8 (3.2) \\
\hline- & - & & & NM_016272 & TOB2 (1.8) \\
\hline \multicolumn{6}{|c|}{ Cell Cycling (GO ID: 0007049) } \\
\hline- & - & - & - & NM_001553 & IGFBP7 (7.5) \\
\hline- & - & - & - & NM_000636 & SOD2 (4.9) \\
\hline- & - & - & - & NM_001924 & GADD45A (1.6) \\
\hline- & - & - & - & AL050044 & GADD45B (3.1) \\
\hline- & - & - & - & AL096865 & RUNX2 (2.4) \\
\hline- & - & - & - & NM_015895 & GMNN (2.6) \\
\hline- & - & - & - & NM_021953 & FOXM1 (1.9) \\
\hline- & - & - & - & NM_002520 & NPM1 (8.5) \\
\hline- & - & - & - & NM_002165 & ID (3.6) \\
\hline- & - & - & - & NM_001553 & IGFBP7 (9.7) \\
\hline- & - & - & - & AB037594 & ING1 (2.1) \\
\hline
\end{tabular}

[43], MSC [44], neural SC [45] and neural progenitor cells [46] we had found self renewal genes to be predominantly upregulated, in cornea (table 2). This is indicative of the presence of early TACs, (Transient cells), with self-renewal properties in cornea. These cells could sustain healthy corneal epithelium independent of
limbal/LEC support. Dua et al [27] have demonstrated the long term conservation of 'central islands' of normal corneal epithelium in patients with total limbal stem cell deficiency as determined clinically by in vivo confocal microscopy. Study on cornea of certain mammals by Majo et al have demonstrated holoclone capacity of the 
Table 3 Candidate genes expressed in GO terms influencing the niche microenvironment, of stem/progenitor cells

\begin{tabular}{|c|c|c|c|c|c|}
\hline \multicolumn{2}{|l|}{ LEC } & \multicolumn{2}{|l|}{ Limbus } & \multicolumn{2}{|l|}{ Cornea } \\
\hline Accession No & Gene Symbol & Accession No & Gene Symbol & Accession No & Gene Symbol \\
\hline \multicolumn{6}{|c|}{ CAM } \\
\hline NM_022843 & PCDH2O (1.9) & NM_002318 & LOXL2 (2.5) & AL109804 & SIGLEC1 (1.7) \\
\hline AL109804 & SIGLEC1 (1.8) & - & - & NM_022121 & PERP (4.9) \\
\hline NM_004360 & $\mathrm{CDH} 1$ (3.1) & - & - & NM_002589 & PCDH7 (3.2) \\
\hline- & - & - & - & NM_004572 & PKP2 (3.8) \\
\hline \multicolumn{6}{|c|}{ Growth factors } \\
\hline- & - & NM_007083 & NUDT6 (1.7) & NM_014624 & S100A6 (5.7) \\
\hline- & - & - & - & U62317 & ECGF1 (2.7) \\
\hline- & - & - & - & AC005234 & TGFA (2.6) \\
\hline- & - & - & - & NM_004494 & HDGF (3.3) \\
\hline \multicolumn{6}{|c|}{ Cytokines } \\
\hline- & - & NM_002350 & LYN (1.2) & NM_199193 & BRE (3.3) \\
\hline- & - & - & - & NM_005625 & SDCBP (2.4) \\
\hline- & - & - & - & NM_021709 & SIVA1 (3.8) \\
\hline- & - & - & - & NM_017801 & CMTM6 (3.9) \\
\hline- & - & - & - & NM_004757 & SCYE1 (7.9) \\
\hline- & - & - & - & NM_016951 & CKLF (3.9) \\
\hline- & - & - & - & U52912 & LEPR (3.5) \\
\hline- & - & - & - & NM_000565 & IL6R (8.7) \\
\hline- & - & - & - & AJ271736 & IL9R (4.2) \\
\hline \multicolumn{6}{|c|}{ Antioxidants } \\
\hline NM_006406 & PRDX4 (4.1) & NM_012094 & PRDX5 (1.6) & NM_000454 & SOD1 (3.9) \\
\hline NM_000636 & SOD2 (3.5) & NM_000636 & SOD2 (1.6) & NM_000636 & SOD2 (4.9) \\
\hline- & - & - & - & NM_002574 & PRDX1 (4.3) \\
\hline- & - & - & - & NM_006793 & PRDX3 (1.9) \\
\hline- & - & - & - & NM_006406 & PRDX4 (7.2) \\
\hline- & - & - & - & NM_012094 & PRDX5 (3.0) \\
\hline- & - & - & - & NM_004528 & MGST3 (3.7) \\
\hline- & - & - & - & NM_018445 & SELS (2.0) \\
\hline- & - & - & - & NM_018833 & TAP2 (2.9) \\
\hline- & - & - & - & NM_000852 & GSTP1 (3.7) \\
\hline \multicolumn{6}{|c|}{ Neurotropins } \\
\hline NM_002615 & SERPINF1(2.4) & NM_002615 & SERPINF1(3.1) & AY029066 & Humanin (4.3) \\
\hline \multicolumn{6}{|c|}{ Immunomodulatory } \\
\hline AL109804 & SIGLEC1 (1.8) & AL035662 & CD40 (1.5) & AF098366 & IGHG1 (5.6) \\
\hline- & - & - & - & NM_030790 & ITFG1 (4.4) \\
\hline- & - & - & - & AL035662 & CD40 (2.3) \\
\hline \multicolumn{6}{|c|}{ Extracellular matrix } \\
\hline - & - & NM_002318 & LOXL2 (2.5) & BC004241 & LAMA4 (2.8) \\
\hline
\end{tabular}

central cornea and showed that the central corneal epithelium, when transplanted to the limbus, could regenerate corneal epithelium [47]. However Sun et al have refuted this and argued that true corneal epithelial $\mathrm{SC}$ are located primarily at the limbus and not in the central cornea [48]. Data from this study supports the latter notion, and further refines the preferential location of SC in the LEC. An ex-vivo study on organ cultured corneas has demonstrated that the central corneal epithelium depicts a regenerative potential in acute wound healing [49]. Some of these differences are clearly species dependent and any oligopotent potential 
of human central cornea is not yet proven. Data from the above reports can be reconciled by proposing that the SC are primarily located at the limbus/LEC and that the central cornea contains cells that are capable of maintaining a sustained regenerative capacity in the absence of a functional limbus, as well as in the uninjured physiological state. This supports the hypothesis that the transition from a SC to a TAC is not abrupt but that there exists a population of cells between these two stages that have an intermediate potential, which we have termed "transient cells", and can migrate to populate the central cornea [27]. In this study presence of enriched TAC related GO terms with significant gene expression in cell cycling, self renewal, cell proliferation in cornea (table 2) is suggestive of the presence of such "transient cells" with self renewal capacity in this region.

iii) Cell proliferation is a property of activated progenitor cells. Upregulated genes for cell proliferation in cornea mainly belonged to TGFB1 and the Ras Oncogene family (table 2). Integrin Beta 1 Binding Protein 1 (ITGB1BP1) involved in disruption of focal cellular adhesion and mobilisation of stem/transient cells via the c-Myc promoter [50] was found to be downregulated in LEC. This gene was further validated by real time PCR. $L Y N$ a tyrosine kinase molecule involved in cell proliferation of haematopoietic stem cells [51] was also found to be upregulated in limbus.

iv) Cell differentiation is a process whereby undifferentiated regenerative cells acquire specialised structural and functional features of mature cells. It was enriched in all the 3 groups. Of the sixty two, cell differentiation genes identified in LEC only five were upregulated (table 2) these were involved in maintaining epithelial cells in an undifferentiated state. However, in limbus of the 43 genes 23 were upregulated, out of which only 3 genes were involved in maintaining the cells in undifferentiated state (KRT19, SOD2, KRT14) (table 2). KRT19 has been identified in epidermal stem/progenitor cell population with a role in negative regulation of differentiation [52]. Lyngholm, M et al identified SOD2 as a marker of limbal SC [53], it was found to be upregulated in LEC, limbus and cornea in this study.

In cornea, of 113 genes expressed, 79 were upregulated and were involved in differentiation, including terminal differentiation (table 2). Retinoic acid pathway involved in inhibition of proliferation of corneal TAC [54] was also expressed in cornea (RXRG, RARRES3, CYP26A1) (table 2). Epidermal Differentiation Complex (EDC) is a family of S100 related genes crucial for terminal differentiation of human epidermis [55]. Of the 18 known S100 genes for EDCs four were upregulated in cornea and one in limbus (table 2). Down-regulation of all these protein complexes was noted in LEC. Apolipoproteins expressed in differentiated cells were found to be upregulated in cornea and absent or downregulated in the LEC and limbus.

v) Negative regulation of cell proliferation, also known as 'cell quiescence', was enriched only in LEC ( $\mathrm{p}$ value: $1.4 \mathrm{E}-2$ ), and LEC stroma (p value: 3.5E-2). SERPINF1 a secreted Neurotropin with potent antiangiogenic properties upregulated in early passage cells in G0 phase as compared to actively proliferating or senescent cells [56] was also found to be upregulated in LEC and limbus.

vi) Cell cycling (GOTERM_BP_ALL: GO: 0007049) refers to replication and segregation of genetic material followed by cell division. Cornea was enriched for this GO term (p value: $2.9 \mathrm{E}-2$ ). However LEC (p value: $2.4 \mathrm{E}-01$ ) and limbus (P value: $5.6 \mathrm{E}-02$ ) were not enriched for this $\mathrm{GO}$ term. Of the 60 genes expressed in cornea, 55 were upregulated and mainly represented G1, G2/M phase including cyclins G1, $H, C$ and cyclin $D$ type binding protein.

vii) Keratins: KRT19 a known epidermal SC marker [52] was also found to be upregulated in LEC and limbus; hence supporting the evidence of presence of SC in these regions. However limbus also had upregulated expression of KRT 14 which is expressed by mitotically active basal cells of stratified epithelium [57] and KRT 13 expressed by suprabasal cells of non-cornified stratified epithelia [58]

\section{Molecular features of OS SC niche components}

Adult SC are influenced by their microenvironment or the niche, which regulates their function. Niche components identified in OS regions included cell adhesion molecules (CAMs), growth factors, cytokines, extracellular matrix and secreted proteins like neurotropins (table 3). E-cadherin, a CAM upregulated in LEC was previously shown to anchor the $\mathrm{SC}$ to the basement membrane and thus aid in SC maintenance [59] and prevent aging of SC [60]. SIGLEC1 a CAM and a cell surface receptor, also upregulated in LEC, has been shown to be involved in epithelial regeneration [61]. Growth factors and cytokines promote proliferation and these were found to be upregulated in cornea (table 3). However IGFBP2 (Insulin Growth Factor Binding Protein 2) which is known to influence epidermal regeneration and SC maintenance [62] was found to be upregulated in LEC. Protection of stem and progenitor cells from oxidative stress is crucial for their sustained maintenance. The GO term detoxifier system (GOTERM_MF_ALL: GO: 0016209) which confers antioxidant protection, was enriched in LEC (P value: 5.0E2 ), cornea (p value: $5.1 \mathrm{E}-3$ ) and limbus (p value: $4.7 \mathrm{E}-2$ ). SOD2 an antioxidant was found to be upregulated in LEC, limbus and cornea (table 3). It was previously shown to prevent the aging of the SC and their niches in human epidermal keratinocytes [60]. We further validated the expression of SOD2 in these regions with real time PCR. 
Unlike the cornea, the stroma of the limbus has been shown to maintain the basal epithelial layer in an undifferentiated condition, preserving the stemness of the SC [63]. Previous studies have shown the presence of a heterogeneous population of cells which include bone marrow derived mesenchymal cells in the limbal stromal region [64] along with the limbal epithelial progenitor cells that have migrated in the process of epithelial mesenchymal transition (EMT) [65]. Similarly we had noted round undifferentiated epithelial and spindle like mesenchymal cells in LEC stroma on histological sections of LEC (marked with white arrow head) (Figure 1I). Therefore we further studied the gene expression profile encoding the GO term "secreted" (extra cellular region GO: 0005576) for its influence on the LEC cells. The absence of CDH1 in LEC stroma, along with activation of LEF1/WNT $\beta$-Catenin signalling pathways in LEC could account for EMT which was similarly reported in a previous study on limbal stroma [66]. LEC stroma was enriched for the tissue metalloproteinase inhibitors (TIMP1, TIMP2), developmental protein FLII (7.2), antioxidants XPA (4.57), DUOX1 (5.11), member of GDNF family GFR $\alpha 4$, and $L M N A$ a nuclear envelope matrix protein, all of which have been reported to be involved with SC maintenance in other tissues $[67,68]$.

Unlike epithelium from different regions, we did not compare the LEC stroma with stroma from other regions. This is a limitation of the current work; however, we were able to compare the gene expression of LEC stroma with published data on limbal stroma [63]. The above mentioned data on LEC stroma is supportive of its role in maintenance of the LEC cells in undifferentiated state.

\section{Canonical pathways on ocular surface}

IPA was used to characterise the enriched canonical metabolic and signalling pathways on the OS epithelial regions (table 4).

\section{i). Metabolic pathways}

Out of 41 molecules involved in energy metabolism in cornea, 35 were upregulated by more than 2 fold indicating active metabolism in this region possibly related to cell division and turn over. Likewise, Karsten et al [69] have noted upregulated expression of oxidative phosphorylation, purine and protein metabolism in neural progenitor cells denoting increased energy consumption and high protein turn over due to active cellular processes like proliferation and cell migration. Cornea also had upregulated expression of related carbohydrate metabolic pathways such as pyruvate, citrate/glycolysis and gluconeogenesis. Cornea was also enriched for glutathione metabolism, which is crucial for maintaining corneal transparency, cell membrane integrity and protection against oxidative stress.
Table 4 Enriched canonical signaling and metabolic pathways in OS epithelial regions

\begin{tabular}{lll}
\hline Canonical metabolic pathways & P-Value & No of genes \\
\hline LEC & & \\
\hline Oxidative Phosphorylation & $4.52 \mathrm{E}-17$ & 29 \\
\hline Ubiquinone biosynthesis & $8.04 \mathrm{E}-12$ & 14 \\
\hline Purine metabolism & 0.00166 & 18 \\
\hline Pyrimidine metabolism & 0.0274 & 9 \\
\hline Limbus & & \\
\hline Pentose Phosphate Pathway & 0.0014 & 5 \\
\hline Oxidative Phosphorylation & 0.00795 & 7 \\
\hline Valine, Leucine and Isoleucine Biosynthesis & 0.00851 & 2 \\
\hline Alanine and aspartate metabolism & 0.0151 & 3 \\
\hline Glycolysis/gluconeogenesis & 0.047 & 4 \\
\hline Cornea &
\end{tabular}

\section{Cornea}

\begin{tabular}{llc}
\hline Oxidative Phosphorylation & $3.48 \mathrm{E}-21$ & 41 \\
\hline Ubiquinone Biosynthesis & $2.14 \mathrm{E}-08$ & 16 \\
\hline Purine metabolism & 0.000118 & 30 \\
\hline Alanine and Aspartate metabolism & 0.000869 & 9 \\
\hline Glutathione metabolism & 0.00607 & 8 \\
\hline Glycolysis/gluconeogenesis & 0.00855 & 12 \\
\hline Lysine biosynthesis & 0.0402 & 2 \\
\hline Citrate cycle & 0.042 & 4 \\
\hline Pyruvate metabolism & 0.0451 & 8 \\
\hline
\end{tabular}

Canonical Signaling Pathways

\begin{tabular}{llc}
\hline LEC & & \\
\hline NRF2-mediated Oxidative Stress Response & $2.29 E-05$ & 16 \\
\hline Nucleotide Excision Repair Pathway & $3.17 \mathrm{E}-05$ & 7 \\
\hline Protein Ubiquitination Pathway & $2.06 \mathrm{E}-05$ & 16 \\
\hline Estrogen Receptor Signaling & $8.79 \mathrm{E}-03$ & 8 \\
\hline Glucocorticoid Receptor Signaling & $1.81 \mathrm{E}-02$ & 13 \\
\hline Limbus & & 7 \\
\hline NRF2-mediated Oxidative Stress Response & $2.81 \mathrm{E}-02$ & 4 \\
\hline Regulation of actin based motility by Rho & $4.51 \mathrm{E}-02$ & \\
\hline Cornea & & 21 \\
\hline NRF2 mediated Oxidative Stress Response & $2.51 \mathrm{E}-04$ & 26 \\
\hline Protein Ubiquitination Pathway & $3.09 \mathrm{E}-07$ & 15 \\
\hline Estrogen Receptor Signaling & $3.67 \mathrm{E}-04$ & 7 \\
\hline Antigen Presentation Pathway & $1.29 \mathrm{E}-03$ & 10 \\
\hline VDR/RXR Activation & $6.31 \mathrm{E}-03$ & 20 \\
\hline Glucocorticoid Receptor Signaling & $3.05 \mathrm{E}-02$ & $2.77 \mathrm{E}-04$ \\
\hline Nucleotide Excision repair & & 7 \\
\hline
\end{tabular}

Studies on side population cells from various tissues have demonstrated that the energy consumption, transcription, translation and metabolism in the undifferentiated and quiescent cells are minimal $[24,70]$. Although oxidative phosphorylation, amino acid, carbohydrate and energy metabolism were found to be enriched in LEC, 
limbus and cornea, the gene expression in these pathways was downregulated in LEC and limbus, which supports the presence of undifferentiated and quiescent cells in these regions.

\section{ii). Signalling pathways}

All the three OS regions were enriched for NRF2 mediated oxidative stress response (table 4 ). It has a role in cell protection during cell cycling.

\section{SC signalling pathways in the OS}

Fevr et al have demonstrated the importance of WNT receptor-beta catenin signalling pathway in maintaining intestinal crypt structures and SC in their niche [71]. It is also crucial for maintaining $\mathrm{HSC}$ in a quiescent state and also has a role in SC self renewal [72]. We had found upregulated expression of molecules, involved in WNT receptor-beta catenin signalling such as LEF1, and CDH1 in LEC. Soluble WNT antagonists (sWA) maintain skin bulge SC quiescence [73] and also contribute to SC pool maintenance in gastric tissue [41]. FRZB1, a soluble WNT antagonist (sWA) was uniquely expressed in LEC. FRZB1 was weakly expressed in microarrays but real-time PCR and immunofluorescence results showed high gene and protein expression of FRZB1 in LEC compared to other regions (Figure 4A, $5 F)$. Planar polar component of WNT pathway, involved in regulation of cell adhesion and motility, was upregulated in cornea only (table 5). Genes related to the Notch [74], Jak/STAT [75], TGF-Beta/BMP [76] and the Hedgehog $(\mathrm{HH})$ signalling pathways involved in regulation of cell proliferation and differentiation in response to cytokines and growth factors; were found to be upregulated in cornea but not in LEC (table 5). HES1, a target gene of Notch signalling pathway, and RBX1 aTGF-Beta gene were further validated with real time PCR.

\section{Comparison of gene expression in OS epithelium with other SC populations}

LEF1 was found to be crucial for maintaining stemness across various SC populations such as embryonic [77], mesenchymal [44] and epithelial [36] SC. In this study it was uniquely upregulated in LEC. Myc genes encode for transcription factors, which activate genes influencing cell proliferation, cell growth, apoptosis and SC selfrenewal. A study on epidermal SC has noted upregulated expression of myc genes in $\alpha 6+/ \mathrm{MHCI}^{+}$cells. These cells have characteristic features of TAC. However, myc genes were found to be downregulated in $\alpha 6+/ \mathrm{MHCI}^{-}$ population of cells consisting of quiescent SC [78]. Myc genes such as $A N X A 1$, TGFB1, FTH1, VAMP8, KRT5, HSPB1 and UGCG were upregulated in cornea and TXN (4.5) in limbus but these genes were downregulated in
LEC. Self renewal genes such as FZD7 [44,78-80], PCNA [69], and STAT3 [77,81-83] expressed in PSC populations (haematopoietic, mesenchymal, epithelial, neuronal and embryonic SC) were also upregulated in cornea.

\section{Comparison with other ocular gene expression studies}

We had noted some similarities with other OS gene expression studies, particularly with regards to KRT19, an epithelial SC marker previously identified in limbus [11]. KRT19 was found to be upregulated in LEC and limbal epithelium in this study. KRT13 a suprabasal epithelial marker [23], was also upregulated in limbus. A study comparing the gene profile of limbal and corneal basal cells in mice has noted preferential expression of epithelial SC genes such as FGFR1 (Fibroblast Growth Factor Receptor 1) and S100A6 (S100 calcium binding protein A6) in limbus [23], however we had noted upregulation of these molecules in the corneal epithelium. This difference could be related to an interspecies variation. We had also noted upregulated expression of CRTAC1, CTSL2, NQO1, KRT12, MAL, IGFBP6, IGFBP7, $S 100 A 10$ in the cornea. These genes were previously identified by Turner et al in their oligonucleotide microarray study on corneal and conjunctival epithelium [84].

\section{Validation of microarray data}

\section{i) Quantitative real-time PCR ( $q P C R$ )}

Relative quantification of genes of interest (FRZB1, RBX1, INTGB1BP1, HES1, SOD2) was performed with real time PCR on OS regions such as limbus, cornea, and conjunctiva in comparison with LEC (figure 4). FRZB1 was found to be significantly expressed in LEC but was absent in all corneal replicates and insignificantly expressed in limbus and conjunctiva (figure 4A). RBX1 was significantly expressed in LEC compared to cornea and conjunctiva (figure 4B). Significant expression of ITGB1BP1 was noted between limbus and LEC with least expression in LEC (figure 4C). Significant expression of HES1 was noted between LEC and cornea and also between LEC and conjunctiva (Figure 4D). Although SOD2 was significantly expressed in all the OS regions posthoc analysis had failed to demonstrate any significant relationship between the groups (Figure 4E).

\section{ii) Immuno fluorescence}

Immunofluorescence of frozen tissue sections of OS epithelium was performed with FRZB1 and HES1 antibodies (Figure 5). A previous study on HES1 expression in mice corneal epithelial stem/progenitor cells has demonstrated that an increased expression of HES1 in these cells was crucial for regulation of corneal development and homeostasis [85]. Intense nuclear staining of HES1 was noted in LEC and the stromal cells adjacent to LEC (figure $5 \mathrm{~A}$ ) as compared to limbus (figure $5 \mathrm{~B}$ ). 


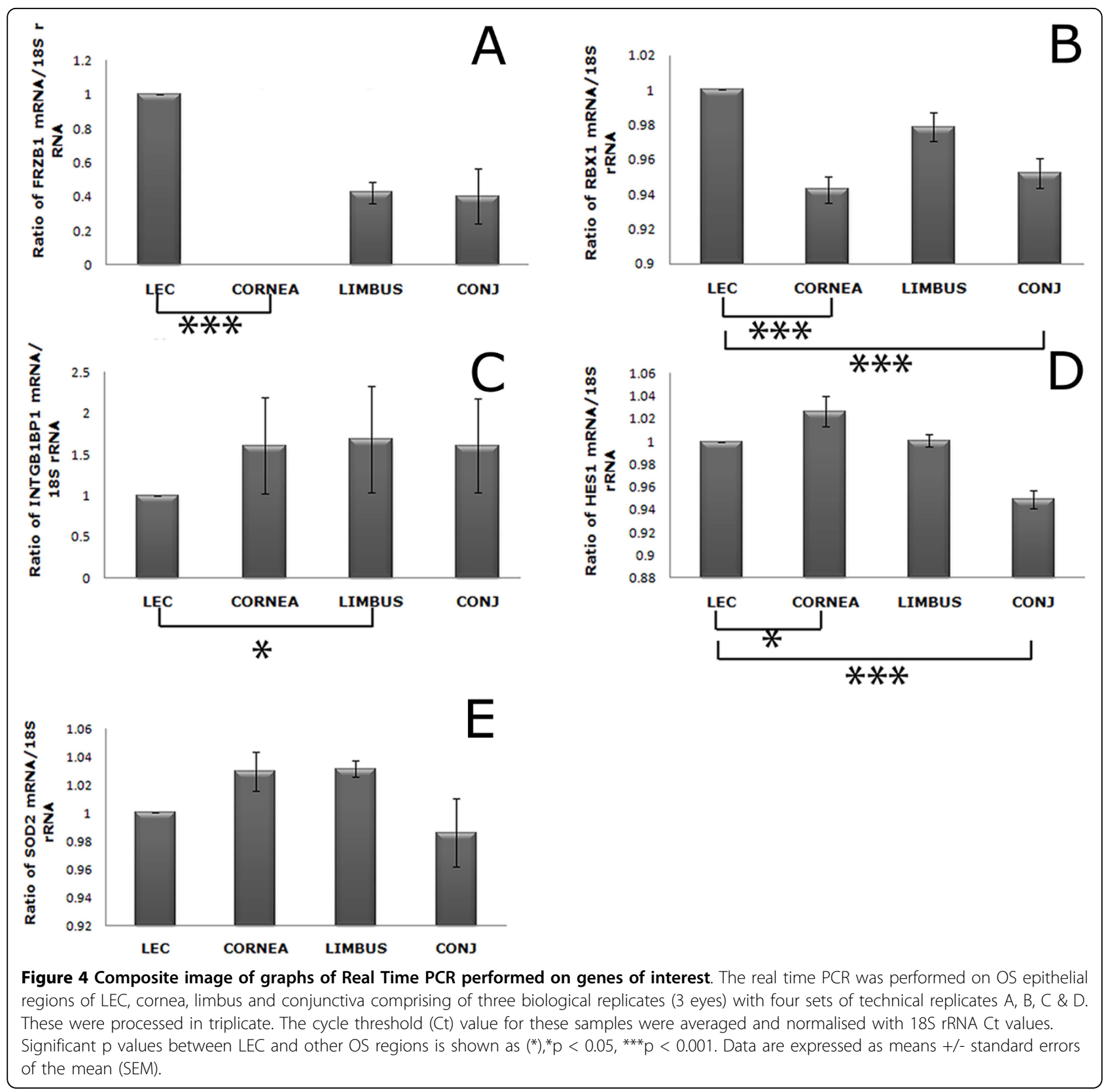

This evidence is supportive of increased proportion of stem progenitor cells in LEC and also in the surrounding LEC stroma. Few cells in the cornea along the basal epithelium also expressed HES1 (Figure 5C). Nuclear staining with FRZB1 was prominently seen in the basal epithelium of the LEC (Figure 5F) and in some areas of the limbus (Figure 5G). Figure 5H shows absence of FRZB1 expression in corneal epithelium.

In summary, gene ontology and gene expression patterns noted in this study are suggestive of LEC being the most metabolically dormant and undifferentiated region as compared to cornea and limbus. LEC was enriched for GO terms related to quiescent adult SC. Upregulated genes in LEC such as CDH1, SERPINF1, LEF1, FRZB1, KRT19, SOD2, EGR1 along with Beta catenin-WNT signalling pathway are known to be involved in SC maintenance. However limbus and cornea had presence of a mixed population of stem/progenitor, and differentiated cells. Similar to LEC limbus was metabolically dormant, but also had upregulated SC signalling molecules related to WNT, TGF-Beta and Hedgehog pathways. Cornea had upregulated gene 


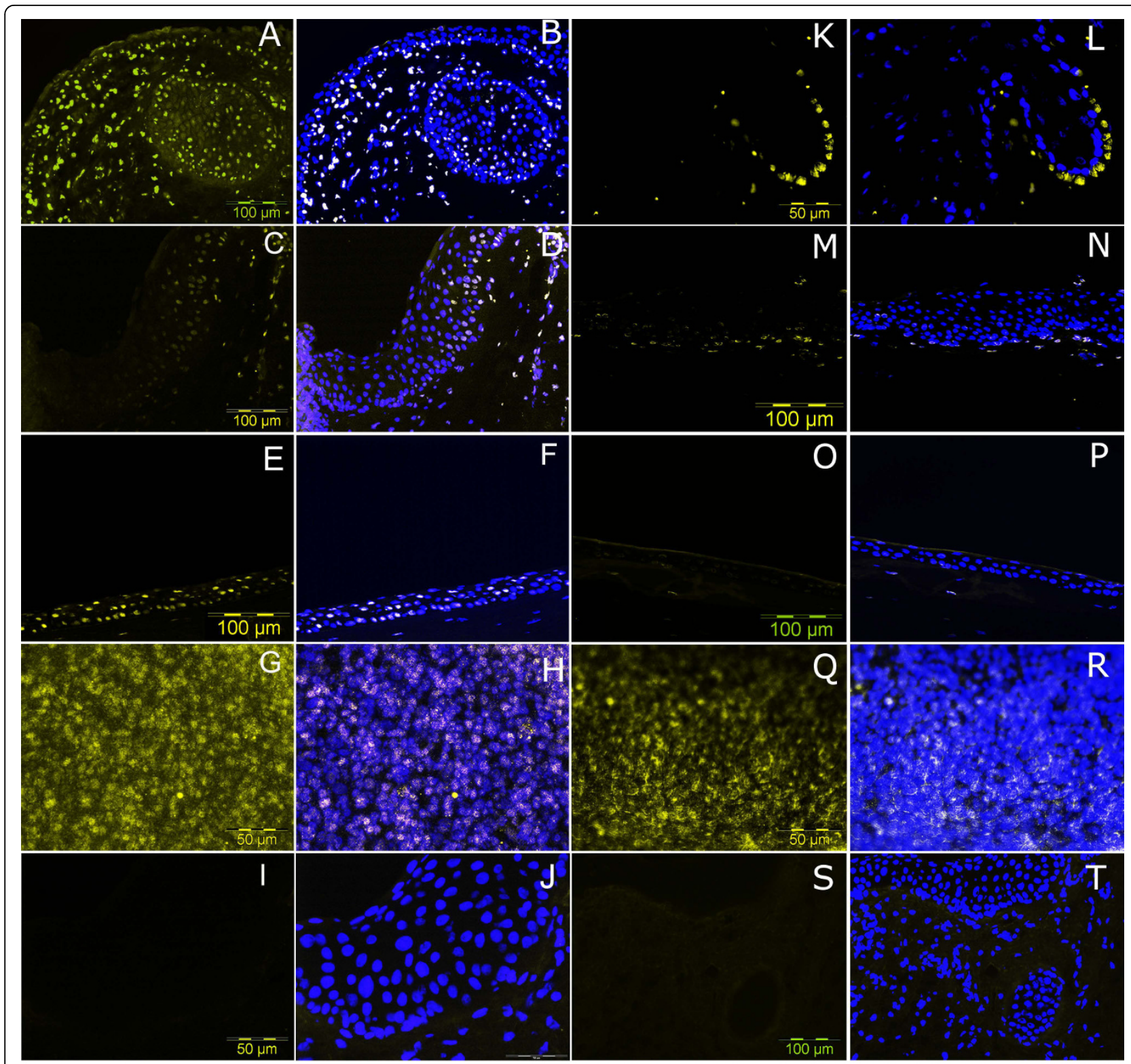

Figure 5 Immuno-fluorescent staining for expression of stem cell molecules on ocular surface epithelium. Immunofluorescence with HES1 and FRZB1 was performed on radial cut sections of LEC ( $A, B, K, L)$, limbus ( $C, D, M, N)$ cornea $(E, F, O, P)$ and tonsil $(G, H, Q, R)$. Images (K, $L, G, H, Q, R, I, J)$ are at 40x magnification, the remainder are at 20x magnification (scale bars shown). HES1 immunofluorescence co-localised with DAPI nuclear dye is shown in images (B. $D, F, H$,). Images $(A, C, E, G)$ show HES1 (TRITC) staining. FRZB1 immunofluorescence co-localised with DAPI dye is shown in images $(L, N, P, R)$. Images $(K, M, O, Q$, ) are of FRZB1 with TRITC dye. Positive staining for HES1 and FRZB1 (B, D, $F, H)$, $(N, P, R)$ is seen as whitish nuclear stain, due to co-localisation of FRZB1 and HES1 (TRITC dye) and nuclear stain DAPI in the cell nuclei. FRZB1 immunofluorescence of LEC $(L)$ is seen as yellow colouration as it intensely stained the nuclei of the basal epithelial cells in the LEC and masked the underlying DAPI staining. Positive nuclear staining of Tonsil with HES1 antibody $(G, H)$ has speckled appearance and FRZB1 (Q, R) appears as a rim around the cell nucleus. Images $(I, J)$ and $(S, T)$ are negative controls for HES1 and FRZB1 antibody respectively.

expression related to cell cycling, self renewal, proliferation, cell differentiation growth factors, cytokines and SC signalling genes in the WNT, Notch, TGF-Beta pathways. This further strengthens the evidence for the presence of long term surviving early TACs (transient cells) with self renewal capacity in the cornea.

\section{Conclusion}

This study is the first to characterise the in situ gene expression profile of laser microdissected LEC and demonstrate the presence of two distinct SC compartments on the OS. We have demonstrated, at the transcriptome level that the LEC has features that appear to 
Table 5 Stem cell signaling pathway genes in OS epithelial regions

\begin{tabular}{|c|c|c|c|c|}
\hline \multirow[t]{2}{*}{ Accession numbers } & \multirow[t]{2}{*}{ Gene symbols } & \multicolumn{3}{|c|}{ Fold change } \\
\hline & & LEC & Limbus & Cornea \\
\hline \multicolumn{5}{|c|}{ WNT signalling pathway } \\
\hline NM_016269 & LEF1 & $(1.2)$ & - & - \\
\hline NM_006261 & $\mathrm{CDH} 1$ & (5.3) & - & $(-5.8)$ \\
\hline NM_013263 & BRD7 & $(-4.0)$ & (1.8) & $(4.0)$ \\
\hline NM_001892 & CSNK1A1 & - & $(4.6)$ & - \\
\hline AF267864 & TBL1XR1 & - & - & (1.9) \\
\hline NM_003507 & FZD7 & - & - & $(2.0)$ \\
\hline NM_022825 & PORCN & - & - & (2.0) \\
\hline NM_018890 & RAC1 & $(-3.0)$ & - & (3.0) \\
\hline NM_001320 & CSNK2B & $(-2.6)$ & - & (2.6) \\
\hline NM_014248 & RBX1 & $(5.6)$ & & $(-5.6)$ \\
\hline \multicolumn{5}{|c|}{ Notch Signalling pathway } \\
\hline NM_014276 & RBPJL & $(-3.9)$ & - & (3.9) \\
\hline NM_005524 & HES1 & $(-1.5)$ & - & $(2.1)$ \\
\hline NM_203283 & RBPJ & - & - & (4.6) \\
\hline NM_033632 & FBXW7 & $(-6.1)$ & - & $(6.1)$ \\
\hline \multicolumn{5}{|c|}{ JAK/STAT Signalling pathway } \\
\hline NM_004232 & sOCS6 & - & - & (3.9) \\
\hline U52912 & LEPR & $(-3.4)$ & $(-2.2)$ & (3.4) \\
\hline U52914 & LEPR & - & - & $(2.3)$ \\
\hline AJ271736 & IL9R & - & $(-4.2)$ & $(4.2)$ \\
\hline NM_000565 & IL6R & - & $(-8.7)$ & $(8.7)$ \\
\hline NM_003150 & STAT3 & - & - & $(1.7)$ \\
\hline NM_000297 & PKD2 & $(-2.8)$ & - & $(2.8)$ \\
\hline NM_014432 & IL20RA & $(-4.2)$ & - & $(4.2)$ \\
\hline \multicolumn{5}{|c|}{ TGF-Beta Signalling pathways } \\
\hline NM_002165 & ID1 & $(-3.6)$ & $(1.5)$ & (3.6) \\
\hline NM_006350 & FST & - & - & $(2.4)$ \\
\hline NM_014248 & RBX1 & $(5.6)$ & - & $(-5.6)$ \\
\hline NM_002165 & ID1 & $(-3.6)$ & $(1.5)$ & (3.6) \\
\hline \multicolumn{5}{|c|}{ BMP Signalling pathway } \\
\hline AL096865 & RUNX2 & $(-2.4)$ & - & $(2.4)$ \\
\hline NM_006350 & FST & - & - & $(2.4)$ \\
\hline \multicolumn{5}{|c|}{ Hedgehog signalling pathway $(\mathrm{HH})$} \\
\hline NM_001892 & CSNK1A1 & - & $(4.5)$ & - \\
\hline NM_016004 & IFT52 & - & $(2.5)$ & - \\
\hline NM_005870 & SAP18 & $(-5.3)$ & $(-3.7)$ & $(6.2)$ \\
\hline
\end{tabular}

The differentially expressed SC signalling molecules in the OS epithelial regions were identified with KEGGS pathways and reactome. Numbers in brackets are fold change. Negative values indicate downregulated and positive values are upregulated gene expression. No values denote absence of gene expression in the region.

be consistent with that of a quiescent SC niche. Although the limbus was metabolically dormant it had a mixed population of differentiated and undifferentiated cells. Our study clearly demonstrates that cornea is the most differentiated and proliferating region. The gene expression of this region is also suggestive of the presence of early TACs with self renewal capacity (transient cells) Clinical evidence supports our findings that cornea has the potential to sustain steady state turnover of its epithelium in healthy ocular conditions and LEC is the potential reservoir of limbal SC. Although a specific limbal SC marker has yet to be elucidated, our findings have identified several genes of interest, which will be further studied as candidate genes to validate their potential as stem cell markers.

\section{Methods}

\section{Donor eye tissue preparation}

This study was carried out at the Queens Medical Centre, University Hospital Nottingham, England with approval of Nottingham Research Ethics Committee (REC NO: OY030202). Protocol was consistent with Tenets of Declaration of Helsinski. Informed, written consent was obtained from relatives of all the donors. The eyes were harvested within 48 hours of death under aseptic conditions using conventional techniques in order to maintain the RNA viability. Four pairs of human donor eyes were collected for microarray study. The inclusion criteria were: i) donors aged between 20 to 70 years; ii) donors of either sex; iv) Eyes with intact and undamaged OS epithelium, confirmed with dissecting microscope and patient history as ascertained from the case notes. The corneoscleral button was dissected from the cadaver eye and processed for sectioning using established techniques within our department [12]. Briefly, a $15 \mathrm{~mm}$ corneal button was trephined maintaining a $3 \mathrm{~mm}$ frill of conjunctiva around the limbus and divided into eight triangular radial segments. Each segment was positioned in the optimum temperature compound (OCT, Emitech Ltd, East Sussex, England) with the long dissected edge parallel to the OCT surface and then gradually frozen using isopentane precooled in liquid Nitrogen. The frozen tissue blocks were stored at $-80^{\circ} \mathrm{C}$ for future cryosectioning.

\section{Processing of Standard probe samples}

Depending on the number of biological samples and their replicates sufficient amount of control samples are required for any microarray study. As it was not possible to generate required amount of control sample with LMD, we followed the reference probe hybrid approach for sample processing as described by Neal and Westwood [86]. Briefly, the reference samples were prepared by pooling the corneal and conjunctival epithelial RNA. The tissue for RNA extraction was obtained by scrapping the OS epithelial regions from the cadaver eyes. This approach generated sufficient amount of reference samples for the microarrays, facilitated better 
comparison between the two regional arrays and also highlighted the variations in gene expression between the biological replicates but not the reference samples. For real time PCR, RNA extraction for each OS region was performed in triplicate from three different cadaver eyes using RNeasy Microkit (Qiagen, Crawley, West Sussex, UK) according to manufacturer's protocol.

\section{Laser Microdissection (LMD)}

Under RNase and DNase free conditions, 6-7 $\mu \mathrm{m}$ serial sections of frozen tissue blocks of corneoscleral buttons were prepared with Jung CM 1900 cryostat (Leica, UK) and examined under light microscope for presence of LEC and also for good epithelial histology of other OS regions. Prior to LMD, sections were placed on polyL-lysine coated PALM $^{\ominus}$ membrane slides, fixed in precooled $70 \% \mathrm{v} / \mathrm{v}$ ethanol for 5 minutes and air dried. Following which, the sections were briefly stained with $0.1 \% \mathrm{w} / \mathrm{v}$ Toludine Blue for 30 seconds, washed in DEPC treated water and air dried. LMD was performed with the $\mathrm{PALM}^{\circ}$ Microbeam systems (Zeiss Instruments, Bernreid, Germany), using the Robo LPC laser function, according to manufacturer's recommended guidelines. The area of interest was cut and catapulted in the caps of collection tubes, coated with special adhesive. Thereafter RLT RNA lysis buffer (QIAGEN) was added to the collection tubes and stored at $-80^{\circ} \mathrm{C}$ until further use. For each of the 4 eyes, multiple LMD samples were collected from five regions creating 5 independent experimental groups; 1) LEC; 2) limbus; 3) cornea; 4) LEC stroma, and 5) conjunctiva.

\section{Total RNA Extraction}

For microarrays total RNA extraction from LMD sections for samples and reference sample was performed with RNeasy kit, including DNase treatment, according to manufacturer's protocols (QIAGEN House, West Sussex, UK). RNA quantity and quality was measured with Picoassay 2100 Bioanalyzer (Agilent Technologies, USA). Samples with concentration ranging between 20$90 \mathrm{pg} / \mu \mathrm{l}$ and an average RIN value (RNA Integrity Number) of 5.1 [32] were used for further analysis.

\section{Preparation of reference sample for Standard Probe}

$1 \mu \mathrm{g}$ of total RNA from each corneal and conjunctival reference sample was mixed and ethanol precipitated by adding 0.1 volumes Sodium Acetate and 2.5 volumes $100 \%$ ETOH followed by incubation at $-20^{\circ} \mathrm{c}$ for $30 \mathrm{~min}-$ utes. Samples were then centrifuged at $21000 \times \mathrm{g}$ at $4^{\circ} \mathrm{C}$ for 15 minutes and the pellet washed in $250 \mu \mathrm{l}$ of $70 \%$ $\mathrm{v} / \mathrm{v}$ ETOH before recentrifugation at $21000 \times \mathrm{g}$ for 5 min. The RNA pellet was dried and resuspended in 10 $\mu \mathrm{l}$ ultra pure, RNase free water followed by quantitation using NanoDrop ND-1000 UV-Vis Spectrophotometer (Labtech International Ltd-UK).

\section{RNA Amplification, labelling of the samples and reference sample}

Each RNA sample and reference sample was further processed for microarray analysis. To $0.2 \mathrm{ng} / 10 \mu \mathrm{l}$ of starting RNA, $0.5 \mu \mathrm{l}$ of 1:5000 diluted spike control (GE Healthcare life Sciences Universal Score card oligonucleotide control), which are sequences from E. coli genes, was added for validation of microarray data. Complimentary RNA (cRNA) amplification was performed with Amino Allyl Message Amp ${ }^{\text {Ta }}$ II aRNA Amplification kit and labelled with $\mathrm{Cy} 3$ and $\mathrm{Cy} 5$ reactive dye [Ambion, (Europe) LTD, UK], the Frequency of Incorporation (FOI) of the $\mathrm{Cy} 3$ and $\mathrm{Cy} 5$ dye in the labelled samples was measured, according to manufacturer's protocols. Quality control of the purified cRNA samples was performed at the end of $1^{\text {st }}$ and $2^{\text {nd }}$ rounds by NanoDrop spectrophotometer. Unsatisfactorily amplified and labelled samples were discarded and new samples were processed.

\section{Microarray hybridisation}

$500 \mathrm{ng}$ of a labelled sample and reference sample with matching FOI were separately blocked with $2 \mu$ l Poly A and $2 \mu \mathrm{l}$ human Cot $1 \mathrm{DNA}$ and then combined. This was followed by ethanol precipitation to generate $2 \mu \mathrm{l}$ of the hybrid probe in nuclease free water. Prior to hybridisation, the 30K Human spotted oligonucleotide glass arrays manufactured in house, (Post-Genomics technologies facility, University of Nottingham, UK), were blocked with appropriate buffers $(5 \times \mathrm{SSC}, 0.2 \% \mathrm{w} / \mathrm{v}$ SDS, $1 \%$ w/v BSA), (SSC buffer: Saline, Sodium Citrate buffer; SDS buffer: Sodium Dodecyl. Sulphate; BSA: Bovine Serum Albumin). The slides were then washed thrice with ultra pure water, $100 \%$ ETOH and spun dried. For hybridisation, $100 \mu \mathrm{l}$ of pre warmed Schott $1 \times$ Hybridisation Buffer was gently added to the hybrid probe, heated to $95^{\circ} \mathrm{C}, 2$ minutes followed by hybridisation on automated hybridisation station TECAN HS 4800 (Tecan UK Ltd) using manufacturers protocols. The conditioned hybridisation station was primed with ultra pure water followed by a $1 \mathrm{~min}$ and a $15 \mathrm{~min}$ wash in $5 \times \mathrm{SSC}, 0.2 \% \mathrm{w} / \mathrm{v}$ SDS, at $50^{\circ} \mathrm{C}$. Next, $100 \mu \mathrm{l}$ of probe was injected onto the slide and hybridised with agitation at $50^{\circ} \mathrm{C}$ for 16 hours, followed by sequential washing in four cycles of $2 \times$ SSC, $0.1 \%$ SDS, 2 cycles of $1 \times$ SSC, $0.1 \%$ SDS, and $0.1 \times$ SSC, $0.2 \%$ SDS at $40^{\circ} \mathrm{C}, 2$ cycles of $0.1 \times \mathrm{SSC}$ at $23^{\circ} \mathrm{C}$, followed by a final cleaning cycle of ultrapure water before drying. On completion of the programme, the slides were covered to protect against light and scanned immediately. 


\section{Scanning and Data analysis}

Hybridised microarray slides were scanned to obtain two coloured digital images on an Agilent BA scanner. The images were further analysed with Gene Pix Pro 6.0 software. Poor spots and spots overlying areas of high background intensities were lassoed and removed from further analysis. However, spots of varying sizes but with good intensities were included in analysis. The raw data was uploaded on BASE (Bio Array Software Environment; (Lund University, Lund, Sweden) which is a MIAME (Minimum Information about a Microarray Experiment) compliant system [87]. The raw data sets were expressed as $\log$ ratio of channel 1/channel 2 intensities or log ratio of Cy5/Cy3 (sample/standard probe). Bioassay sets created from the raw data sets were further filtered to refine the data by removing 'noise'. Following filtrations, intra-array Lowess normalisation was performed on BASE, and the bioassay sets were then imported to J-Express Pro software (http:// www.molmine.com; MolMine AS, Norway). In J-Express inter array scale normalisation was performed on the imported data sets. Further statistical analysis of the data was performed in J-Expresspro using a feature subset selection algorithm (FSS) for two unpaired groups comparison with following parameters: $P$ value was selected for score method, individual ranking of the genes was performed and fold change values were $\log (2)$ transformed.

\section{Significance Analysis of Microarrays (SAM)}

Differentially expressed gene list was generated from the FSS derived gene list ( $\mathrm{p}$ value $\leq 0.05$ ) by performing SAM on the data to determine the fold change and the False Discovery Rate (FDR). Cutoff limit of FDR was set to $\leq 5 \%$ and genes with FDR above this limit were excluded from the analysis. Following SAM the five individual gene lists generated for each of the OS regions were merged to form an overlapping gene list for each region.

\section{Principal Component Analysis (PCA)}

PCA evaluates variation between the samples. The $2 \mathrm{D}$ plots representing the samples (Figure 2 left) and the genes (Figure 2 right) were generated following FSS analysis in J-Expresspro. The variance of axes was displayed in percentage. The data with greatest variation is clustered at the first principal component axis.

\section{Gene Ontology (GO)}

The enriched GO terms for each region was determined by uploading the significant gene list for each region individually on the Database for Annotation, Visualization, and Integrated Discovery (DAVID) v6.7, 2008, (http://david.abcc.ncifcrf.gov) and the data was analysed according to published methodology $[88,89]$. GO terms associated with the biological processes $(\mathrm{GO} \sim \mathrm{BP})$ were mostly considered for analysis. Statistical significance of the GO terms was established by Fishers Exact T test. GO terms with $\mathrm{p}$ values $<0.05$ were considered statistically significant.

\section{Canonical pathways on Ingenuity Pathway Analysis}

The microarray data was also analysed with Ingenuity Pathways Analysis (IPA) version 7.6 (Ingenuity ${ }^{\odot}$ Systems, http://www.ingenuity.com). IPA identified the canonical signalling and metabolic pathways from the IPA library that were most significant to the data set. The significance of the association between the data set and the canonical pathway was measured as a ratio and the $p$ value calculated with Fischer Exact test. The data discussed in this publication have been deposited in NCBI's Gene Expression Omnibus and are accessible through GEO Series accession number GSE19035 http://www.ncbi.nlm.nih.gov/geo/query/acc.cgi? acc=GSE19035.

\section{Quantitative Gene Expression Analysis (Real-time PCR)}

The relative quantification of $\mathrm{mRNA}$ for genes of interest on OS epithelium (LEC, limbus, cornea, and conjunctiva) was performed with real-time PCR. Approximately $1 \mathrm{ng} / \mu \mathrm{l}$ concentration of RNA was used for cDNA synthesis using QuantiTect Reverse Transcription Kit (QIAGEN) according to manufacturer's protocol. Inventoried Taqman assays (Applied Biosystems, Foster City, CA) were used for selected genes of interest. Each reaction was performed in triplicate with final reaction volume of $20 \mu \mathrm{l}$. The reaction components comprised of, $10 \mu \mathrm{l} 2 \times$ Taqman Gene Expression Master Mix (Applied Biosystems), $1 \mu$ l of $20 \times$ Taqman Assay probes (Applied Biosystems), $1 \mu \mathrm{l}$ cDNA (1:2 dilutions), $8 \mu$ l nuclease free water (Promega UK, Southampton, UK). Non template, reverse transcriptase negative and positive cDNA from Universal Human Reference RNA (Stratagene, La Jolla, CA) were run as controls. Amplification was performed on the Mx3005P multicolour 96 well PCR system (Stratagene Europe, Amsterdam, Netherlands) with the following parameters, $50^{\circ} \mathrm{C}$ for $2 \mathrm{~min}$ and then $95^{\circ} \mathrm{C}$ for $10 \mathrm{~min}$ followed by 45 cycles of $95^{\circ} \mathrm{C}$ for 15 seconds and $60^{\circ} \mathrm{C}$ for 1 minute. Data analysis was performed on Mxpro ver 4.2 software to measure the threshold cycle $(\mathrm{Ct})$ for each reaction. Set of triplicate $\mathrm{Ct}$ values for each sample was averaged. Normalisation of the average sample gene expression was performed with the average $\mathrm{Ct}$ value of $18 \mathrm{~S}$ rRNA endogenous gene control for that sample. 


\section{Statistical Analysis of Real time PCR Data}

The real time PCR data was statistically analysed on SPSS ver 16. The average normalised $\mathrm{Ct}$ values of gene of interest for each of the OS regions were subjected to Levene's test, to measure the equality of variance. The normally distributed data was then analysed with one way analysis of variance (ANOVA) with Bonferonni's posthoc test. Non parametric distributed samples were analysed by Kruskal-Wallis test followed by Mann-Whitney test, $\mathrm{p}$ value $<0.05$ was considered statistically significant.

\section{Immunohistochemistry}

Six micron frozen tissue sections mounted on 2\% 3-aminopropyltriethoxysilane (APES), (SIGMA) coated slides were fixed in acetone followed by three washes with wash solution consisting of $1 \% \mathrm{PBS}, 1 \% \mathrm{BSA}$ and $0.1 \% \mathrm{v} /$ $\mathrm{v}$ Triton-X for 5 minutes each. The sections were then blocked using 10\% v/v goat serum (Invitrogen, UK), followed by over night incubation with primary antibody prepared in the above mentioned wash solution at $4^{\circ} \mathrm{C}$. Primary antibodies were rabbit anti human polyclonal FRZB (H-170), dilution, 1:100 (Santa Cruz Biotechnology, INC Europe); and HES1, rabbit anti human, dilution 1:100, (US Biological, USA). Slides were washed 3 times for 5 minutes in wash solution followed by detection of the primary with secondary antibody Goat anti-rabbit conjugated Alexa Fluor 555 (Dilution 1:300; Invitrogen Ltd, Paisley, Scotland) for 30 minutes. This was followed by washes with above mentioned wash solution for 5 minutes and then counterstained with nuclear stain DAPI (4', 6-diamidino-2-phenylindole) (Dilution: $25 \mu \mathrm{l}$ in $5 \mathrm{ml}$ PBS of stock solution $1 \mathrm{mg}$ in 4 ml PBS, Santacruz Biotechnology, UK) for 4 minutes followed by further washing. Slides mounted with fluorescent mounting medium (Dako, Ely, UK) were visualised using the B51X fluorescent microscope with software CELL^F (Olympus UK Ltd, UK).

\section{Acknowledgements \\ I gratefully acknowledge financial support to this project from Royal College of Surgeons of Edinburgh, UK. I would like to thanks Toshana Foster and Stacy Mutch (research technicians) for their support with microarray experiments. I wish to thanks Mr K Tsintzas, School of Biomedical sciences, University of Nottingham, UK, for his helpful advice on real-time PCR data analysis.}

\section{Author details}

'Division of Ophthalmology and Visual Sciences, B-Floor, Eye \& ENT Building Queen's Medical Centre, Derby Road, Nottingham, UK. Department of Pathology, A-Floor, West Block, Queen's Medical Centre, Derby Road, Nottingham, UK.

\section{Authors' contributions}

BBK was involved in sample collection and processing and also performed microarray, real-time PCR and immunohistochemistry experiments and its analysis. HSD and PJT helped and supervised over the analysis and upload of microarray data on GEO profile. HSD conceived the study and HSD, PJT,
BBK, DGP, AH and VAS participated in its design. HSD and AH had supervisory role and looked after the administration and financial aspect of the project. BBK created a draft of the manuscript, HSD, PJT, AH, and IM helped in editing the manuscript. DGP is supervisor for lasermicrodissection and advised on performing the procedure. IM had advised on data analysis and trouble shooting of real time PCR experiments. AMY helped with immunofluorescence experiment. All authors have read and approved the manuscript.

Received: 29 April 2010 Accepted: 29 September 2010 Published: 29 September 2010

\section{References}

1. Schermer A, Galvin S, Sun T: Differentiation-related expression of a major $64 \mathrm{~K}$ corneal keratin in vivo and in culture suggests limbal location of corneal epithelial stem cells. J Cell Biol 1986, 103:49-62.

2. Di lorio E, Barbaro V, Ferrari S, Ortolani C, De Luca M, Pellegrini G: Q-FIHC: quantification of fluorescence immunohistochemistry to analyse p63 isoforms and cell cycle phases in human limbal stem cells. Microsc Res Tech 2006, 69:983-991.

3. Schlotzer-Schrehardt U, Kruse FE: Identification and characterization of limbal stem cells. Exp Eye Res 2005, 81:247-264.

4. Kasper M: Patterns of cytokeratins and vimentin in guinea pig and mouse eye tissue: evidence for regional variations in intermediate filament expression in limbal epithelium. Acta Histochem 1992, 93:319-332.

5. Cotsarelis G, Cheng SZ, Dong G, Sun T, Lavker RM: Existence of slowcycling limbal epithelial basal cells that can be preferentially stimulated to proliferate: implications on epithelial stem cells. Cell 1989, 57:201-209.

6. Chen W, Hara K, Tian Q, Zhao K, Yoshitomi T: Existence of small slowcycling Langerhans cells in the limbal basal epithelium that express ABCG2. Exp Eye Res 2007, 84:626-634.

7. Lauweryns B, van den Oord JJ, De Vos R, Missotten L: A new epithelial cell type in the human cornea. Invest Ophthalmol Vis Sci 1993, 34:1983-1990.

8. Dua HS, Shanmuganathan VA, Powell-Richards AO, Tighe PJ, Joseph A Limbal epithelial crypts: a novel anatomical structure and a putative limbal stem cell niche. Br J Ophthalmol 2005, 89:529-532.

9. Lavker RM, Sun TT: Heterogeneity in epidermal basal keratinocytes: morphological and functional correlations. Science 1982, 215:1239-1241.

10. Lavker RM, Sun TT: Epidermal stem cells. J Invest Dermatol 1983, 81:121s-127s.

11. Shanmuganathan VA, Foster T, Kulkarni BB, Hopkinson A, Gray T, Powe DG, Lowe J, Dua HS: Morphological characteristics of the limbal epithelial crypt. Br J Ophthalmol 2007, 91:514-519.

12. Yeung AM, Schlotzer-Schrehardt U, Kulkarni B, Tint NL, Hopkinson A Dua HS: Limbal epithelial crypt: a model for corneal epithelial maintenance and novel limbal regional variations. Arch Ophthalmol 2008, 126:665-669.

13. Schofield R: The relationship between the spleen colony-forming cell and the haemopoietic stem cell. Blood Cells 1978, 4:7-25.

14. Spradling A, Drummond-Barbosa D, Kai T: Stem cells find their niche. Nature 2001, 414:98-104.

15. Fuchs $E$, Tumbar T, Guasch G: Socializing with the neighbors: stem cells and their niche. Cell 2004, 116:769-778.

16. Scoville DH, Sato T, He XC, Li L: Current view: intestinal stem cells and signaling. Gastroenterology 2008, 134:849-864.

17. Arai F, Hirao A, Ohmura M, Sato H, Matsuoka S, Takubo K, Ito K, Koh GY, Suda T: Tie2/angiopoietin-1 signaling regulates hematopoietic stem cell quiescence in the bone marrow niche. Cell 2004, 118:149-161.

18. Fukada S, Uezumi A, Ikemoto M, Masuda S, Segawa M, Tanimura N, Yamamoto H, Miyagoe-Suzuki Y, Takeda S: Molecular signature of quiescent satellite cells in adult skeletal muscle. Stem Cells 2007, 25:2448-2459.

19. Umemoto $T$, Yamato $M$, Nishida $K$, Yang J, Tano $Y$, Okano T: Limbal epithelial side-population cells have stem cell-like properties, including quiescent state. Stem Cells 2006, 24:86-94.

20. Figueira EC, Di Girolamo N, Coroneo MT, Wakefield D: The phenotype of limbal epithelial stem cells. Invest Ophthalmol Vis Sci 2007, 48:144-156.

21. Adachi W, Ulanovsky H, Li Y, Norman B, Davis J, Piatigorsky J: Serial analysis of gene expression (SAGE) in the rat limbal and central corneal epithelium. Invest Ophthalmol Vis Sci 2006, 47:3801-3810. 
22. Ding Z, Dong J, Liu J, Deng SX: Preferential gene expression in the limbus of the vervet monkey. Mol Vis 2008, 14:2031-2041.

23. Zhou M, Li XM, Lavker RM: Transcriptional profiling of enriched populations of stem cells versus transient amplifying cells. A comparison of limbal and corneal epithelial basal cells. J Biol Chem 2006, 281:19600-19609.

24. Akinci MA, Turner HC, Taveras M, Wolosin JM: Differential gene expression in the pig limbal side population; implications for stem cell cycling, replication and survival. Invest Ophthalmol Vis Sci 2009, 50(12):5630-8.

25. Li DQ, Chen Z, Song XJ, de Paiva CS, Kim HS, Pflugfelder SC: Partial enrichment of a population of human limbal epithelial cells with putative stem cell properties based on collagen type IV adhesiveness. Exp Eye Res 2005, 80:581-590.

26. Budak MT, Alpdogan OS, Zhou M, Lavker RM, Akinci MA, Wolosin JM: Ocular surface epithelia contain ABCG2-dependent side population cells exhibiting features associated with stem cells. J Cell Sci 2005, 118:1715-1724.

27. Dua HS, Miri A, Alomar T, Yeung AM, Said DG: The role of limbal stem cells in corneal epithelial maintenance: testing the dogma. Ophthalmology 2009, 116:856-863.

28. Davanger $M$, Evensen $A$ : Role of the pericorneal papillary structure in renewal of corneal epithelium. Nature 1971, 229:560-561.

29. Thoft RA, Friend J: The $X, Y, Z$ hypothesis of corneal epithelial maintenance. Invest Ophthalmol Vis Sci 1983, 24:1442-1443.

30. Sharma A, Coles WH: Kinetics of corneal epithelial maintenance and graft loss. A population balance model. Invest Ophthalmol Vis Sci 1989, 30:1962-1971.

31. Barrandon Y: Crossing boundaries: stem cells, holoclones, and the fundamentals of squamous epithelial renewal. Cornea 2007, 26:S10-12.

32. Doherty JM, Geske MJ, Stappenbeck TS, Mills JC: Diverse adult stem cells share specific higher-order patterns of gene expression. Stem Cells 2008, 26:2124-2130.

33. Edwards YJ, Bryson $\mathrm{K}$, Jones DT: A meta-analysis of microarray gene expression in mouse stem cells: redefining stemness. PLOS ONE 2008, 3:e2712.

34. Potten CS, Loeffler M: Stem cells: attributes, cycles, spirals, pitfalls and uncertainties. Lessons for and from the crypt. Development 1990, 110:1001-1020

35. Zhou P, Byrne C, Jacobs J, Fuchs E: Lymphoid enhancer factor 1 directs hair follicle patterning and epithelial cell fate. Genes Dev 1995, 9:700-713.

36. Jamora C, DasGupta R, Kocieniewski P, Fuchs E: Links between signal transduction, transcription and adhesion in epithelial bud development. Nature 2003, 422:317-322.

37. Yasuda J, Tsuchiya A, Yamada T, Sakamoto M, Sekiya T, Hirohashi S: Nemolike kinase induces apoptosis in DLD-1 human colon cancer cells. Biochem Biophys Res Commun 2003, 308:227-233.

38. Levanon D, Goldstein RE, Bernstein $Y$, Tang H, Goldenberg D, Stifani $S$, Paroush Z, Groner Y: Transcriptional repression by AML1 and LEF-1 is mediated by the TLE/Groucho corepressors. Proc Natl Acad Sci USA 1998, 95:11590-11595.

39. Lyngholm M, Hoyer PE, Vorum H, Nielsen K, Ehlers N, Mollgard K: Immunohistochemical markers for corneal stem cells in the early developing human eye. Exp Eye Res 2008, 87:115-121.

40. Zipori D: The stem state: plasticity is essential, whereas self-renewal and hierarchy are optional. Stem Cells 2005, 23:719-726.

41. van der Flier LG, Clevers $\mathrm{H}$ : Stem cells, self-renewal, and differentiation in the intestinal epithelium. Annu Rev Physiol 2009, 71:241-260.

42. Trentin A, Glavieux-Pardanaud C, Le Douarin NM, Dupin E: Self-renewal capacity is a widespread property of various types of neural crest precursor cells. Proc Natl Acad Sci USA 2004, 101:4495-4500.

43. Noh M: Self Renewal Pattern-Associated Genes and Their Role In Adult Stem Cell Function. Thesis Massachusetts Institute of Technology, Division of Biological Engineering 2006.

44. Song $L$, Webb NE, Song $Y$, Tuan RS: Identification and functional analysis of candidate genes regulating mesenchymal stem cell self-renewal and multipotency. Stem Cells 2006, 24:1707-1718.

45. Karpowicz P, Willaime-Morawek S, Balenci L, DeVeale B, Inoue T, van der Kooy D: E-Cadherin regulates neural stem cell self-renewal. J Neurosci 2009, 29:3885-3896.

46. Nakamura Y, Sakakibara S, Miyata T, Ogawa M, Shimazaki T, Weiss S, Kageyama R, Okano H: The bHLH gene hes1 as a repressor of the neuronal commitment of CNS stem cells. J Neurosci 2000, 20:283-293.
47. Majo F, Rochat A, Nicolas M, Jaoude GA, Barrandon Y: Oligopotent stem cells are distributed throughout the mammalian ocular surface. Nature 2008, 456:250-254

48. Sun TT, Tseng SC, Lavker RM: Location of corneal epithelial stem cells. Nature 463:E10-11, discussion E11.

49. Chang $C Y$, Green $C R$, McGhee CN, Sherwin T: Acute wound healing in the human central corneal epithelium appears to be independent of limbal stem cell influence. Invest Ophthalmol Vis Sci 2008, 49:5279-5286.

50. Bouvard D, Millon-Fremillon A, Dupe-Manet S, Block MR, Albiges-Rizo C: Unraveling ICAP-1 function: toward a new direction? Eur J Cell Biol 2006, 85:275-282.

51. O'Laughlin-Bunner B, Radosevic N, Taylor ML, Shivakrupa, DeBerry C, Metcalfe DD, Zhou M, Lowell C, Linnekin D: Lyn is required for normal stem cell factor-induced proliferation and chemotaxis of primary hematopoietic cells. Blood 2001, 98:343-350.

52. Michel M, Torok N, Godbout MJ, Lussier M, Gaudreau P, Royal A, Germain L: Keratin 19 as a biochemical marker of skin stem cells in vivo and in vitro: keratin 19 expressing cells are differentially localized in function of anatomic sites, and their number varies with donor age and culture stage. J Cell Sci 1996, 109(Pt 5):1017-1028.

53. Lyngholm M, Vorum $H$, Nielsen $K$, Ostergaard M, Honore B, Ehlers $N$ : Differences in the protein expression in limbal versus central human corneal epithelium-a search for stem cell markers. Exp Eye Res 2008, 87:96-105

54. Kruse FE, Tseng SC: [Retinoic acid inhibits the proliferation of dividing cells in peripheral corneal epithelium]. Ophthalmologe 1993, 90:662-668.

55. Marenholz I, Volz A, Ziegler A, Davies A, Ragoussis I, Korge BP, Mischke D: Genetic analysis of the epidermal differentiation complex (EDC) on human chromosome 1q21: chromosomal orientation, new markers, and a 6-Mb YAC contig. Genomics 1996, 37:295-302.

56. Pignolo RJ, Cristofalo VJ, Rotenberg MO: Senescent WI-38 cells fail to express EPC-1, a gene induced in young cells upon entry into the G0 state. J Biol Chem 1993, 268:8949-8957.

57. Romano RA, Ortt K, Birkaya B, Smalley K, Sinha S: An active role of the DeltaN isoform of p63 in regulating basal keratin genes $\mathrm{K} 5$ and $\mathrm{K} 14$ and directing epidermal cell fate. PLoS One 2009, 4:e5623.

58. Lindberg K, Brown ME, Chaves HV, Kenyon KR, Rheinwald JG: In vitro propagation of human ocular surface epithelial cells for transplantation. Invest Ophthalmol Vis Sci 1993, 34:2672-2679.

59. Song X, Zhu CH, Doan C, Xie T: Germline stem cells anchored by adherens junctions in the Drosophila ovary niches. Science 2002, 296:1855-1857.

60. Pan L, Chen S, Weng C, Call G, Zhu D, Tang H, Zhang N, Xie T: Stem cell aging is controlled both intrinsically and extrinsically in the Drosophila ovary. Cell Stem Cell 2007, 1:458-469.

61. Choi HULS, Shim NR, Lee HW, Baek SY, Kim JB, Kim BS, Yoon S: Expression of the ED3 Antigen and its Upregulation after Cyclophosphamide Treatment on Basal Epithelial Cells of Rat Stratified Squamous Epithelium. Korean J Anat 2003, 36:1-10.

62. Kim DS, Cho HJ, Yang SK, Shin JW, Huh CH, Park KC: Insulin-like growth factor-binding protein contributes to the proliferation of less proliferative cells in forming skin equivalents. Tissue Eng Part A 2009, 15:1075-1080.

63. Espana EM, Kawakita T, Romano A, Di Pascuale M, Smiddy R, Liu CY, Tseng SC: Stromal niche controls the plasticity of limbal and corneal epithelial differentiation in a rabbit model of recombined tissue. Invest Ophthalmol Vis Sci 2003, 44:5130-5135.

64. Polisetty N, Fatima A, Madhira SL, Sangwan VS, Vemuganti GK: Mesenchymal cells from limbal stroma of human eye. Mol Vis 2008 , 14:431-442.

65. Kawakita T, Espana EM, He H, Li W, Liu CY, Tseng SC: Intrastromal invasion by limbal epithelial cells is mediated by epithelial-mesenchymal transition activated by air exposure. Am J Pathol 2005, 167:381-393.

66. Kim K, Lu Z, Hay ED: Direct evidence for a role of beta-catenin/LEF-1 signaling pathway in induction of EMT. Cell Biol Int 2002, 26:463-476.

67. Schmidt JA, Avarbock MR, Tobias JW, Brinster RL: Identification of GDNFRegulated Genes Important for Spermatogonial Stem Cell Self-Renewal in the Rat. Biol Reprod 2009, 81:56-66.

68. Pekovic $\mathrm{V}$, Hutchison $\mathrm{CJ}$ : Adult stem cell maintenance and tissue regeneration in the ageing context: the role for A-type lamins as 
intrinsic modulators of ageing in adult stem cells and their niches. $J$ Anat 2008, 213:5-25

69. Karsten SL, Kudo LC, Jackson R, Sabatti C, Kornblum HI, Geschwind DH: Global analysis of gene expression in neural progenitors reveals specific cell-cycle, signaling, and metabolic networks. Dev Biol 2003, 261:165-182.

70. Rochon C, Frouin V, Bortoli S, Giraud-Triboult K, Duverger V, Vaigot P, Petat C, Fouchet P, Lassalle B, Alibert O, Gidrol X, Pietu G: Comparison of gene expression pattern in SP cell populations from four tissues to define common "stemness functions". Exp Cell Res 2006, 312:2074-2082.

71. Fevr T, Robine $S$, Louvard $D$, Huelsken J: Wnt/beta-catenin is essential for intestinal homeostasis and maintenance of intestinal stem cells. Mol Cell Biol 2007, 27:7551-7559.

72. Suda T, Arai F: Wnt signaling in the niche. Cell 2008, 132:729-730.

73. Tumbar T, Guasch G, Greco V, Blanpain C, Lowry WE, Rendl M, Fuchs E: Defining the epithelial stem cell niche in skin. Science 2004, 303:359-363.

74. Blanpain C, Fuchs E: Epidermal homeostasis: a balancing act of stem cells in the skin. Nat Rev Mol Cell Biol 2009, 10:207-217.

75. Wu R, Sun S, Steinberg BM: Requirement of STAT3 activation for differentiation of mucosal stratified squamous epithelium. Mol Med 2003, 9:77-84.

76. Langlands K, Down GA, Kealey T: Id proteins are dynamically expressed in normal epidermis and dysregulated in squamous cell carcinoma. Cancer Res 2000, 60:5929-5933.

77. Wei CL, Miura T, Robson P, Lim SK, Xu XQ, Lee MY, Gupta S, Stanton L, Luo Y, Schmitt J, Thies S, Wang W, Khrebtukova I, Zhou D, Liu ET, Ruan YJ, Rao M, Lim B: Transcriptome profiling of human and murine ESCs identifies divergent paths required to maintain the stem cell state. Stem Cells 2005, 23:166-185.

78. Kocer SS, Djuric PM, Bugallo MF, Simon SR, Matic M: Transcriptional profiling of putative human epithelial stem cells. BMC Genomics 2008, 9:359.

79. Assou S, Le Carrour T, Tondeur S, Strom S, Gabelle A, Marty S, Nadal L, Pantesco V, Reme T, Hugnot JP, Gasca S, Hovatta O, Hamamah S, Klein B, De Vos J: A meta-analysis of human embryonic stem cells transcriptome integrated into a web-based expression atlas. Stem Cells 2007, 25:961-973.

80. Melchior K, Weiss J, Zaehres H, Kim YM, Lutzko C, Roosta N, Hescheler J, Muschen M: The WNT receptor FZD7 contributes to self-renewal signaling of human embryonic stem cells. Biol Chem 2008, 389:897-903.

81. Venezia TA, Merchant AA, Ramos CA, Whitehouse NL, Young AS, Shaw CA, Goodell MA: Molecular signatures of proliferation and quiescence in hematopoietic stem cells. PLoS Biol 2004, 2:e301.

82. Kidder BL, Yang J, Palmer S: Stat3 and c-Myc genome-wide promoter occupancy in embryonic stem cells. PLoS One 2008, 3:e3932.

83. Abeyta MJ, Clark AT, Rodriguez RT, Bodnar MS, Pera RA, Firpo MT: Unique gene expression signatures of independently-derived human embryonic stem cell lines. Hum Mol Genet 2004, 13:601-608.

84. Turner HC, Budak MT, Akinci MA, Wolosin JM: Comparative analysis of human conjunctival and corneal epithelial gene expression with oligonucleotide microarrays. Invest Ophthalmol Vis Sci 2007, 48:2050-2061.

85. Nakamura T, Ohtsuka T, Sekiyama E, Cooper L, Kokubu H, Fullwood NJ, Barrandon $Y$, Kageyama R, Kinoshita S: Hes1 regulates corneal development and the function of corneal epithelial stem/progenitor cells. Stem Cells 2008, 26:1265-1274.

86. Neal SJ, Westwood JT: Optimizing experiment and analysis parameters for spotted microarrays. Methods Enzymol 2006, 410:203-221.

87. Saal LH, Troein C, Vallon-Christersson J, Gruvberger S, Borg A, Peterson C: BioArray Software Environment (BASE): a platform for comprehensive management and analysis of microarray data. Genome Biol 2002, 3: SOFTWARE0003.

88. Dennis G Jr, Sherman BT, Hosack DA, Yang J, Gao W, Lane HC, Lempicki RA: DAVID: Database for Annotation, Visualization, and Integrated Discovery. Genome Biol 2003, 4:P3.

89. da Huang W, Sherman BT, Lempicki RA: Systematic and integrative analysis of large gene lists using DAVID bioinformatics resources. Nat Protoc 2009, 4:44-57.

doi:10.1186/1471-2164-11-526

Cite this article as: Kulkarni et al:: Comparative transcriptional profiling of the limbal epithelial crypt demonstrates its putative stem cell niche characteristics. BMC Genomics 2010 11:526.

\section{Submit your next manuscript to BioMed Central and take full advantage of:}

- Convenient online submission

- Thorough peer review

- No space constraints or color figure charges

- Immediate publication on acceptance

- Inclusion in PubMed, CAS, Scopus and Google Scholar

- Research which is freely available for redistribution 